\title{
Do Bank Regulation and Supervision Displace Bank Auditing?
}

\author{
Aloke (Al) Ghosh \\ Fulbright Distinguished Chair \\ Zicklin School of Business \\ Baruch College, City University of New York \\ New York, NY 10010 \\ Aloke.Ghosh@baruch.cuny.edu \\ Henry Jarva \\ Assistant Professor \\ Department of Accounting \\ Aalto University School of Business \\ P.O. Box 21210, 00076 Aalto, Finland \\ Henry.Jarva@aalto.fi \\ and \\ Stephen G. Ryan \\ Professor of Accounting \\ Stern School of Business, New York University \\ 44 West Fourth Street \\ New York, NY 10012 \\ sryan@stern.nyu.edu
}

September 2017

We thank the participants of the accounting research seminars at the University of Groningen, Hanken School of Economics, Norwegian School of Economics, Pennsylvania State University, and Indian School of Business in Hyderabad for useful comments. 


\title{
Do Bank Regulation and Supervision Displace Bank Auditing?
}

\begin{abstract}
We hypothesize that bank regulatory and supervisory activities substitute for bank auditing activities, providing auditors with incentives to expend less effort on audits of banks than on audits of similar firms not subject to regulation and supervision. We show that banks exhibit fewer internal control and accounting problems, as measured by the frequencies of disclosed material internal control weaknesses and financial statement restatements, than do similar firms. We show that auditors expend less effort, as indicated by lower audit fees and shorter audit report lags, in audits of banks than in audits of similar firms, more so when bank regulation and supervision are more intense. Lastly, we show that banks are more likely than similar firms to exhibit two types of earnings management that are of minor concern to bank regulators and supervisors but have capital market consequences and so should concern auditors: more frequent small positive earnings changes and longer strings of earnings increases. Prior research shows that these types of earnings management have capital market consequences, which suggests they may lead to reduced market discipline over banks. We expect these results to be of interest to bank and auditing policymakers.
\end{abstract}




\section{Introduction}

A central feature of banks is they are regulated and supervised under extensive banking laws and regulations. Moreover, bank supervision involves periodic on-site examination and offsite monitoring activities that overlap considerably with auditing activities. In this study, we examine whether bank regulation and supervision displace bank auditing by reducing the audit effort required to generate sufficient audit evidence to provide the desired level of assurance, leading to lower audit effort in audits of banks than in audits of similar unregulated firms. We define audit effort broadly to include personnel time and quality, audit planning, test of controls, and substantive and analytical procedures.

Bank regulation and supervision arise to address two primary policy concerns, the interaction of which yields a distinct benefit-cost trade-off for auditors in choosing their optimal level of audit effort. First, banks are often viewed as opaque due to their complex and interrelated on- and off-balance sheet exposures (Morgan 2002). The individual and collective value and risk of these exposures are difficult for banks to convey to outsiders and for outsiders to evaluate, especially during periods of financial system stress (Flannery et al. 2013). This difficulty is particularly high for banks that expand beyond traditional lending and depositacceptance activities to engage in derivatives, securities, and other complex transactions (Barth et al. 2009; Acharya 2014; Acharya and Ryan 2016). Moreover, banks are subject to various agency conflicts due to their high leverage and the existence of information asymmetries between banks and their debt and equity claimants, as well as among these claimants (Beatty and Liao 2014; Acharya and Ryan 2016). Banks' economic complexity, opacity, and agency conflicts yield information risk that increases investor demand for high quality audits, all else being equal (Jensen and Meckling 1976; Watts and Zimmerman 1986). We expect this “audit 
demand effect” to increase billed hours, as auditors must work longer to complete higher quality audits, and perhaps also to increase billed hourly rates, as auditors may need to devote personnel with more experience or specialized skills to audit banks.

Second, as "the primary backstop providers of liquidity in the economy and issuers of federally guaranteed deposits to households,” banks are critical to financial system stability and macroeconomic health (Acharya and Ryan 2016). Bank regulators and supervisors' primary responsibility is to ensure banks' safety and soundness. In fulfilling this responsibility, bank regulators and supervisors pay close attention to banks' accounting and internal controls. For example, for some accounting topics such as loan losses, bank regulators provide more detailed implementation guidance than is available in GAAP (Ryan 2011). Bank regulators require regulated banks and bank holding companies to prepare detailed and standardized regulatory reports in conformance with regulatory accounting principles ("RAP”) each quarter. Bank regulators make these reports publicly available on their websites to enhance market discipline of banks (Pettway and Sinkey 1980; Badertscher et al. 2016). Bank regulators specify (a relatively small number of) deviations of RAP from generally accepted accounting principles (“GAAP”) when they deem such “prudential filters” to further regulatory goals (Barth and Landsman 2010). Many of the activities of bank supervisors parallel those of bank auditors. Bank supervisors conduct on-site examinations of banks every 12 to 18 months (Nicoletti 2016; Keeley 2017). As central parts of these examinations, supervisors evaluate the adherence of banks’ accounting to RAP, the adequacy of banks' allowance for loan losses, banks' earnings quality, and the effectiveness of banks' internal controls. Supervisors report examination results to banks' management and boards of directors. Between examinations, bank supervisors conduct ongoing off-site monitoring of banks' safety and soundness using a wide range of information, 
particularly banks' quarterly regulatory reports, and in the context of banks' most recent examination results. To the extent that auditors can rely on the activities of bank regulators and supervisors, these activities yield a "substitution effect" that we expect reduces the audit effort necessary for bank auditors to provide the desired level of assurance. ${ }^{1}$

Owing to the substantial overlap of the activities of bank regulators and particularly bank supervisors with those of bank auditors, we expect that the substitution effect to dominate the audit demand effect, and thus we propose and test two related hypotheses. First, we hypothesize that banks exhibit fewer internal control and accounting problems than do similar firms not subject to regulation and supervision ("control firms"). Second, we hypothesize that auditors expend less effort on audits of banks than on audits of control firms. The conceptual underpinning for both hypotheses is that bank supervisors' periodic on-site examinations and ongoing off-site monitoring of banks, as well as their communication of examination results to banks’ management and directors, reduce two key determinants of banks' audit risk: inherent risk, i.e., the likelihood that banks’ financial statements are materially misstated; and control risk, i.e., the likelihood that banks' internal control systems fail to prevent such material misstatements.

We test both of these hypotheses on a comprehensive sample of publicly traded banks and two samples of control firms: (1) non-depository credit institutions (two-digit SIC code 61$)^{2}$

\footnotetext{
${ }^{1}$ The activities of bank regulators and supervisors also likely complement those of bank auditors to some extent. For example, bank regulators and supervisors likely understand the economics of individual banks and the banking system better than auditors, and bank auditors likely understand the application and limitations of accounting matters better than regulators and supervisors. Owing to the substantial overlap of the activities of bank regulators and particularly supervisors with those of bank auditors, we expect the substitution effect to dominate any complementarity effect, and so we focus on the substitution effect.

${ }^{2}$ To be a bank as defined in the Bank Holding Company Act of 1956, an institution must both make loans and accept deposits. Non-depository credit institutions do the former but not the latter. The lack of deposits also exempts these institutions from regulation under the Federal Deposit Insurance Act.
} 
and (2) all non-banks in the highest five percent of the ratio of accounts receivable (which includes loan and lease receivables) to total assets. We believe the first of these control samples comprises the closest available unregulated firms to banks. We employ the broader and larger second control sample to demonstrate the robustness of our results.

We test the first hypothesis using disclosed material weaknesses in internal control over financial reporting as the proxy for internal control problems (Ashbaugh-Skaife et al. 2007) and restatements of prior period financial statements as the proxy for accounting problems (Palmrose and Scholz 2004; Kinney et al. 2004; Hennes et al. 2014). Consistent with this hypothesis, we find that banks are significantly less likely than control firms to report material weaknesses in internal controls and to restate their financial statements, controlling for other variables that prior research shows to be associated with internal control weaknesses and restatements.

We test the second hypothesis using two measures of audit effort: (1) audit fees (Simunic and Stein 1996) and (2) audit report lag, i.e., the elapsed time between the fiscal year end and the audit report date (Ashton et al. 1987; Bamber et al. 1993; and Ghosh and Tang 2015). Auditing standards require auditors to respond to increases in audit risk by increasing the extent of audit procedures. ${ }^{3}$ Prior research shows that more extensive audits require auditors to work more hours, increasing both audit fees (Houston et al. 1999; Bell et al. 2001; Bedard and Johnstone 2004) and audit report lags (Bronson et al. 2011). Consistent with this hypothesis, we find that on average auditors charge significantly less for audits of banks than for audits of control firms

\footnotetext{
${ }^{3}$ Public Company Accounting Oversight Board (PCOAB), Auditing Standard No. 8, Audit Risk (AS 1101 under the PCAOB's December 2016 reorganization of auditing standards); Auditing Standard No. 12, Identifying and Assessing Risks of Material Misstatement (AS 2110); and Auditing Standard No. 13, The Auditor's Responses to the Risks of Material Misstatement (AS 2301).
} 
and that the average audit report lag is significantly shorter for banks than for control firms, controlling for other variables that prior research shows are associated with audit effort.

The primary threat to inference in our study is the possibility that factors other than bank regulation and supervision explain why audits of banks pose less audit risk than do audits of control firms. Although we cannot rule out this possibility altogether, we conduct two analyses to provide support for bank regulation and supervision as a causal explanation for the reduced audit effort in audits of banks. First, motivated by prior research evidence that (less stringent) bank regulators (are more likely to) exercise accounting-related forbearance (Gallemore 2016; Costello et al., 2016), we test whether bank auditors expend less effort when bank regulation and supervision are more intense. We employ two time-series measures (a numerical index of restrictions in the text of banking regulations and the natural logarithm of the annual budget of federal regulators) and one cross-sectional measure (Agarwal et al.’s 2014 estimate of the difference in the supervisory ratings received by state-chartered banks in alternating examinations from their state supervisors versus from on-average more stringent federal supervisors $^{4}$ ) of the intensity of bank regulation and supervision. We find that audit effort in audits of banks is lower when bank regulation and supervision are more intense.

Second, we examine two types of earnings management that we expect to be more likely to occur as auditor effort decreases: (1) the frequency of reporting small positive earnings changes and (2) the length of strings of consecutive earnings increases. We conjecture that these types of earnings management typically accumulate to relatively small amounts of retained earnings, and thus they have slight effects on banks' solvency ratios and are of minor concern to bank regulators and supervisors. This conjecture is consistent with the absence of any mention of

\footnotetext{
${ }^{4}$ We thank Amit Seru for graciously providing us with this measure.
} 
these types of earnings management in bank supervisory manuals. In contrast, a large empirical literature documents such earnings management by public firms in general and by public banks in particular (Burgstahler and Dichev 1997; Beatty et al. 2002), as well as significant capital market consequences of such earnings management (Bartov et al. 2002; Brown and Caylor 2005). The existence of capital market consequences suggests that these types of earnings management lead to reduced market discipline over banks. We find that banks are more likely than control firms to exhibit both of these types of earnings management.

We contribute to the banking and auditing literatures by providing evidence consistent with auditors expending less effort in auditing banks than in auditing control firms, owing to the overlap of the activities of bank regulators and supervisors with those of auditors. We emphasize that our evidence does not suggest that the aggregate monitoring of banks' financial reporting by bank regulators, supervisors, and auditors differs from the monitoring of similar firms' financial reporting by auditors alone, it only suggests that the monitoring conducted by bank auditors is less. Because of the importance of banks to financial system stability and macroeconomic health, a compelling question is what incremental costs arise when bank auditors, as financial reporting specialists, expend less effort on bank audits due to the existence of bank regulation and supervision. We provide evidence that this reduced audit effort leads to types of earnings management that likely have minor effects on banks' solvency ratios but have capital market consequences documented by prior research that may lead to reduced market discipline over banks. We expect these results to be of interest to bank and auditing policymakers. 


\section{Background and Hypothesis Development}

\subsection{Banking Background ${ }^{5}$}

\subsubsection{Bank Regulation and Regulators}

In the United States, banks are subject to a complex set of laws and regulations (“regulations”) that restrict banks' allowed activities, specify minimum capital and liquidity levels, and govern other matters. The primary goal of these regulations is to ensure the safety and soundness of individual banks and especially of the banking system.

Banking regulations exhibit cycles in stringency over time (Ryan 2007). For example, during the regulatory period from the Great Depression to the 1970s, the Banking Act of 1933 prohibited bank holding companies from owning or being owned by nonfinancial companies and from underwriting most securities. During the deregulatory period in the early to mid-1980s, the Depository Institutions and Monetary Control Act of 1980 phased out interest rate ceilings and allowed thrift institutions to expand their activities significantly. During the regulatory period in the late 1980s and early 1990s, the Federal Deposit Insurance Corporation Improvement Act of 1991 ("FDICIA") required regulators to take prompt corrective action when banks' leverage capital ratios fall below the levels deemed well-capitalized. As discussed below, FDICIA also includes various requirements regarding banks' financial reporting, auditing, and internal control. During the deregulatory period in the late 1990s, the Gramm-Leach-Bliley Act of 1999 allowed regulated banks to underwrite securities and financial holding companies to perform all types of financial services somewhere within their corporate structures. During the postfinancial-crisis regulatory period, the Dodd-Frank Wall Street Reform and Consumer Protection

\footnotetext{
${ }^{5}$ Much of the discussion in this section is drawn from Board of Governors of the Federal Reserve System (2017). To avoid clutter, we only cite material from this document that is not widely available from other sources.
} 
Act of 2010 imposed many prudential regulations on large bank holding companies, including increased risk-based capital and liquidity requirements, credit exposure concentration limits and reporting requirements, periodic stress tests, requirements to plan for rapid and orderly resolution of the institution in the event of financial distress or failure, requirements to establish risk committees, and enhanced public disclosure requirements. Efforts to roll back Dodd-Frank and other bank regulations are currently underway in Congress (Richardson et al. 2017).

Even the most stringent banking laws and regulations can have the intended effects only if bank regulators and supervisors adequately enforce banks' adherence to these rules. Under the “dual banking system,” individual banks may be nationally or state chartered, and bank regulation and supervision are conducted by overlapping sets of federal regulators and state banking departments. National banks are primarily supervised by the Office of the Comptroller of the Currency (“OCC”), a federal regulator. State banks that elect to become members of the Federal Reserve System (state member banks) are primarily supervised by the Federal Reserve, a federal regulator, and their state banking departments. State banks that are not members of the Federal Reserve System (state nonmember banks) are primarily supervised by the FDIC, a federal regulator, and their state banking departments. All banks accepting insured deposits are also supervised by the FDIC. ${ }^{6}$

Individual banks may be owned by bank holding companies, which may apply and qualify to be financial holding companies. Bank holding companies typically engage in lending,

\footnotetext{
${ }^{6}$ Recognizing that the dual banking system and multiple federal bank regulators could lead to inconsistencies in bank regulation and supervision, in 1978 Congress created the Federal Financial Institutions Examination Council ("FFIEC"), an interagency body, to promote consistency in these activities. The FFIEC currently is composed of the chairs of the FDIC and the National Credit Union Administration, the Comptroller of the Currency, a governor of the Federal Reserve, a state banking director, and the director of the Consumer Financial Protection Bureau. The FFIEC has developed uniform examination principles and standards as well as uniform regulatory reporting forms and systems for federally supervised banks.
} 
deposit acceptance, and any other allowed activities through their individual bank subsidiaries. Financial holding companies may engage in activities not allowed in individual banks, such as insurance underwriting and merchant banking, through non-bank subsidiaries (Ryan 2007; Avraham et al. 2012). The Federal Reserve has supervisory authority over all bank holding companies, regardless of how their subsidiary banks are chartered and supervised.

FDICIA imposes two important internal control and accounting requirements on banks with assets above $\$ 500$ million ( $\$ 1$ billion as of December 2005). ${ }^{7}$ First, FDICIA requires these banks to provide the Federal Deposit Insurance Corporation (“FDIC”) with externally audited annual financial statements. Second, FDICIA requires bank managements to assess and certify the adequacy of their internal controls. ${ }^{8}$ This requirement is of particular relevance to our study. Control risk is a key component of audit risk. Particularly prior to the effective dates of Sections 302 and 404 of SOX, FDICIA's requirements should reduce the internal control risk of banks relative to that of non-banks (Altamuro and Beatty 2010). Moreover, we expect bank supervisors to require banks with identified internal control deficiencies to remediate those deficiencies promptly, further reducing banks’ control risk.

\subsubsection{Bank Supervision}

Bank supervision involves the periodic on-site examination and ongoing off-site monitoring of banks' financial condition and risks; the adequacy of banks' accounting, internal control, and risk management systems; and banks' compliance with applicable laws and

\footnotetext{
712 CFR 363, Annual Independent Audits and Reporting Requirements. Part 363 of FDICIA initially specified that these requirements apply to banks holding assets above a threshold of $\$ 150$ million. The FDIC changed this threshold to \$500 million upon its adoption of Part 363 in 1993 to avoid imposing costs on very small banks.

${ }^{8}$ Similar requirements became applicable to non-banks only after Sections 302 and 404 of the SarbanesOxley Act of 2002 ("SOX”) became effective for accelerated filers in 2003 and 2004, respectively (Altamuro and Beatty 2010).
} 
regulations. These activities overlap considerably with those of bank auditing. For example, much like auditors' risk-based approach to auditing, the Federal Reserve indicates that it employs a risk-focused approach to supervision (Board of Governors of the Federal Reserve System 2017). Under this approach, the Federal Reserve first identifies the primary risks faced by a bank. The Federal Reserve then assesses the bank's ability to measure, monitor, and control those risks given its (1) board and senior management oversight; (2) policies, procedures, and risk limits; (3) risk monitoring and management information systems; and (4) internal controls.

On-site examinations of individual banks and bank holding companies generally occur every 12 to 18 months, depending on the organization's size, supervisory rating, and extent of non-banking assets, as well as supervisory resource constraints (Nicoletti 2016; Keeley 2017). For state banks, the primary federal supervisor coordinates its on-site examinations with the state supervisor, with the two supervisors generally conducting examinations in rotation under the "alternating examination program" (Agarwal et al. 2014). The results of an examination, which include a confidential supervisory rating of the bank's overall condition, are reported to the bank's board of directors and management. The supervisory rating system is referred to as CAMELS, an acroynm for its six components: (1) capital adequacy, (2) asset quality, (3) management and administration, (4) earnings, (5) liquidity, and (6) sensitivity to market risk. The overall and component CAMELS ratings efficiently communicate supervisors' overall assessments of banks as well as any specific issues that raise concern or require attention.

Between examinations, bank supervisors use many sources of financial and other information, most importantly banks' quarterly regulatory reports, to monitor banks. The primary report for individual banks is the Consolidated Reports of Condition and Income ("Call Reports”). These reports provide the raw data for the Uniform Bank Performance Report, which 
presents ratios that can be compared across banks and time to detect unusual levels of or significant changes in a bank's financial condition. The primary report for bank holding companies is the Consolidated Financial Statements for Bank Holding Companies (FR Y-9C). The Federal Reserve indicates it uses an automated system to estimate an organization's CAMELS rating based on its prior examination results and subsequent quarterly Call Report or FR Y-9C filings (Board of Governors of the Federal Reserve System 2017).

If a supervisor determines that a bank or bank holding company has problems that affect its safety and soundness, the supervisor may take formal or informal actions to ensure that the organization's management and directors undertake measures to address the problems (Keeley 2017). For example, the supervisor may enter into a written agreement with, issue a cease-anddesist order or prompt-corrective-action directive to, or levy a fine against the organization.

\subsection{Bank Complexity, Opacity, and Agency Conflicts}

Considerable research summarized in Acharya and Ryan (2016) suggests that the quality of banks' financial reporting is central to the stability of the financial system ("stability"). Although a debate exists as to whether stability is enhanced by bank transparency or bank opacity, the traditional and still dominant view is that transparency enhances stability (Morgan 2002; Nier and Baumann 2006; Acharya and Ryan 2016). ${ }^{9}$ Prior theoretical and empirical research provides numerous bases for this view. For example, banks' effectiveness as monitors provides them with comparative advantages in lending to information-sensitive borrowers (Diamond 1984). Banks' high leverage multiplies their risk and exacerbates various agency problems, such as asset substitution (Jensen and Meckling 1976) and underinvestment when the

\footnotetext{
${ }^{9}$ See Dang et al. (2014), Holmström (2015), and Acharya and Ryan (2016) for discussion of the opposing view that bank opacity enhances stability.
} 
benefits of investment primarily accrue to debtholders (Myers 1977). Such agency problems are exacerbated further by information asymmetries between banks and their debt and equity claimants, as well as among these claimants (Beatty and Liao 2014; Acharya and Ryan 2016).

Despite the perceived benefits of bank transparency, banks are often viewed as opaque due to their complex and interrelated on- and off-balance sheet exposures, the individual and collective values and risk of which are difficult for banks to convey to outsiders and for outsiders to evaluate. This difficulty likely enhances banks' ability to manage or obscure their accounting numbers. Prior empirical research providence evidence supporting this view. Morgan (2002) shows that banks receive more split credit ratings (i.e., different bond ratings from different rating agencies) than do non-banks, a result he attributes to banks' greater opacity. He further shows that banks' opacity varies with their asset composition, increasing with their proportions of loans and trading assets. Flannery et al. (2013) provide evidence that bank opacity increases during periods of financial system stress, when the valuations of financial assets become harder to determine and more strongly correlated.

We expect that the difference in opacity between banks and non-banks has widened over time, as banks have shifted their activities from relatively understandable deposit-acceptance and lending activities, i.e., traditional financial intermediation, to less easily understandable nontraditional activities such as derivatives trading, securitization, and the provision of various forms of contingent financing. Banks' economic exposures resulting from these activities often exhibit concentrated or correlated risks or state-contingent liquidity requirements, and these 
exposures often are partly or wholly off-balance sheet (Barth et al. 2009; Acharya 2014; Acharya and Ryan 2016). ${ }^{10}$

Banks’ increasing economic complexity has been accompanied by increasing length and complexity of their financial reports. Accounting standard setters have written many complex and lengthy standards for financial instruments and transactions to try to adequately portray their economics. ${ }^{11}$ Despite banks' provision of far more extensive financial report information in compliance with the requirements of these standards (Guay et al. 2016), we expect the individual and collective values and risk of banks' exposures to have become more difficult for banks to convey to outsiders and for outsiders to evaluate.

\subsection{Hypotheses and Empirical Proxies}

\subsubsection{Engagement Risk and Audit Risk}

Auditors' decisions whether to bid for potential engagements, the prices at which to bid, and the effort needed to provide the desired level of assurance depend on the risk of the engagements (Bedard and Johnstone 2004). Overall engagement risk has three interrelated components: (1) clients' business risk, i.e., the possibility that clients' financial condition deteriorates, in the limit leading to client failure; (2) auditors' business risk, i.e., the possibility of litigation or reputational costs to auditors from their associations with clients; and (3) audit risk, i.e., the possibility that auditors fail to detect material misstatements in financial statements due

\footnotetext{
${ }^{10}$ In large part reflecting the income generated by these nontraditional activities, the average bank's noninterest revenues as a percentage of net operating revenues increased from below $20 \%$ in the 1970 s to around 50\% by 2009 (Barth et al. 2009). A portion of this increase is attributable to generally declining interest rates from 1981 to 2009, however.

${ }^{11}$ Notable examples of these standards include FAS 133 (1998) and FAS 161 (2009) for derivatives (Accounting Standard Codification Section 815) and FAS 140 (2000), FIN 46(R) (2003), FAS 166 (2009), and FAS 167 (2009) for securitizations (Accounting Standards Codification Sections 860 and 810).
} 
to error or fraud. In our investigation of whether bank regulation and supervision displace auditing, we focus on audit risk, because it is the component of engagement risk that is most directly reduced by audit effort.

In the standard (textbook) model (e.g., Johnstone, Gramling and Rittenberg 2014), audit risk has three, by construction distinct, components: (1) inherent risk, i.e., the likelihood that material misstatements of clients' financial statements exist due to factors other than failures of their internal control systems; (2) control risk, i.e., the likelihood that clients' internal control systems fail to prevent material misstatements; and (3) detection risk, i.e., the likelihood the auditor fails to detect material misstatements not prevented by clients' internal control systems. We expect bank regulation and supervision to reduce banks' inherent risk and control risk, and thus to reduce the incentive for auditors to expend effort on audits of banks.

\subsubsection{Frequency of Internal Control and Accounting Problems}

Bank supervisors monitor banks' internal control and accounting systems through periodic on-site examinations and ongoing off-site monitoring. We expect this scrutiny to reduce the inherent risk and control risk components of audit risk for audits of banks relative to audits of control firms, and thus to reduce the risk of material misstatements of banks' financial statements. We formally state this hypothesis in the alternative as:

Hypothesis 1: Banks exhibit fewer internal control and accounting problems than do control firms.

\subsubsection{Audit Effort}

It is theoretically unclear whether auditors should expend more or less effort on audits of banks than on audits of control firms. Auditors might work more on audits of banks than on audits of control firms because of banks' greater complexity, opacity, and agency conflicts. 
These bank characteristics increase the relative benefits of higher quality audits to the investors and contracting parties of banks than to these claimants of control firms. Higher bank audit quality increases the informativeness and reliability of banks' financial statements, and thereby reduces the need for banks' investors and contracting parties to protect themselves by reducing the prices they are willing to pay for securities and by requiring contractual protections such as collateral, respectively. To satisfy this demand for higher audit quality, auditors of banks must expend more effort by increasing the number of billed hours and/or by devoting more experienced and/or specialized staff to engagements, increasing the average billed hourly rate.

On the other hand, auditors might work less on audits of banks than on audits of control firms because of the overlap of the activities of bank regulators and particularly supervisors with the activities of bank auditors. Due to this substitution effect, auditors of banks need to perform less extensive audit planning and substantive testing than do auditors of control firms to provide a given level of assurance.

Although the two effects yield opposing predictions, we expect the substitution effect to dominate the audit demand effect owing to the extent of overlap of the activities of bank regulators and supervisors with those of auditors. Relatedly, many aspects of bank regulation and supervision reduce the inherent and control risk components of audit risk. This expectation yields our second hypothesis stated in the alternative:

Hypothesis 2: Auditors exert lower effort on audits of banks than on audits of control firms.

We expect Hypothesis 2 to hold more strongly when bank regulation and supervision are more intense, for example, when regulators and supervisors use more sophisticated or sensitive 
approaches such as the Federal Reserve's risk-focused approach (Board of Governors of the Federal Reserve System 2017).

\section{Empirical Models and Variables}

\subsection{Frequencies of Internal Control and Accounting Problems}

We employ two dependent variables in our tests of Hypothesis 1. First, we proxy for problems in banks’ internal control using an indicator for material weaknesses in internal control (Ashbaugh et al. 2007). FDICIA requires banks to disclose all such weaknesses, as do Sections 302 and 404 of SOX for all firms. INTERNAL_WEAKNESS denotes firm-years with disclosed material internal control weaknesses. Second, we proxy for banks' accounting problems using an indicator for financial statement restatements. These restatements arise from GAAP violations and thus suggest audit failures (Palmrose and Scholz 2004; Kinney et al., 2004; Hennes et al. 2014). ${ }^{12}$ ACC_RESTATEMENT denotes firm-years with restatements of financial statements. ${ }^{13}$ We denote INTERNAL_WEAKNESS and ACC_RESTATEMENT collectively by $Y$.

The main test variable in our tests of Hypothesis 1 is an indicator for banks, denoted $B A N K$. As discussed below, we control for numerous client and auditor characteristics that prior research finds are associated with internal control and accounting problems. In addition, when the dependent variable $Y$ is INTERNAL_WEAKNESS (ACC_RESTATEMENT), we control for

\footnotetext{
${ }^{12}$ In untabulated analysis, we also proxy for both internal control and accounting problems using auditor resignations (Krishnan and Krishnan 1997; Shu 2000; Hennes et al. 2014). If banks exhibit fewer internal control and accounting problems than do control firms, bank auditors have fewer reasons to resign from audit engagements. However, compared to the proxies for these problems in the tabulated analyses, auditor resignations are more likely to capture the components of engagement risk other than audit risk. For example, prior research shows that auditors are more likely to resign when clients exhibit greater financial distress (Schwartz and Soo 1995), more corporate governance problems (Lee et al. 2004), and greater litigation risk (Krishnan and Krishnan 1997; Simunic and Stein 1996).

${ }^{13}$ All indicator variables in the paper take a value of one when a firm or firm-year exhibits the specified condition and zero otherwise.
} 
ACC_RESTATEMENT (INTERNAL_WEAKNESS). We denote the $Y$ variable that is controlled for in a given model by $Y_{-} C O N T R O L$.

Following prior research examining internal control weaknesses (Altamuro and Beatty 2010) ${ }^{14}$ and financial statement restatements (Palmrose and Scholz 2004; Kinney et al. 2004; Hennes et al. 2008), we use the following logistic model to explain the probability that $Y$ equals one, denoted $\operatorname{Prob}(Y=1)$, in terms of BANK and control variables (collectively denoted $X){ }^{15}$

$$
\begin{aligned}
\operatorname{Prob} & (Y=1)=\mathrm{e}^{\mathrm{X} \beta} /\left(1+\mathrm{e}^{\mathrm{X} \beta}\right) \text {, where } \\
\mathrm{X} \beta= & \beta_{0}+\beta_{1} \text { BANK }+\beta_{2} L \text { LogASSETS }+\beta_{3} R O A+\beta_{4} L O S S+\beta_{5} L E V E R A G E \\
& +\beta_{6} G O O D W I L L+\beta_{7} M \& A+\beta_{8} \text { FOREIGN }+\beta_{9} M T B \\
& +\beta_{10} G O I N G \_C O N C E R N+\beta_{11} Y \_C O N T R O L+\beta_{12} B U S Y \_M O N T H \\
& +\beta_{13} B I G 4+\beta_{14} I S P E C+\text { year fixed effects. }
\end{aligned}
$$

Because $\operatorname{Prob}(Y=1)$ is not directly observable, we estimate equation (1) with $Y$ as the dependent variable. Hypothesis 1 predicts that the coefficient $\beta_{1}$ on $B A N K$ is negative.

Equation (1) controls for numerous client characteristics. We selected these characteristics based on prior research findings that firms that have less resources to invest in internal control systems, have undergone major organizational changes, and are more complex or otherwise stress auditors' resources exhibit more frequent internal control and accounting problems (e.g., Ge and McVay 2005; Ashbaugh-Skaife et al. 2007; Doyle et al. 2007a,b).

We control for the resources that clients have available to establish effective internal control systems using the natural logarithm of total assets (LogASSETS), net income divided by total assets (ROA), an indicator variable for negative net income (LOSS), and the ratio of total

\footnotetext{
${ }^{14}$ Altamuro and Beatty (2010) show how FDICIA's internal control requirements affected insured depository institutions with assets of $\$ 500$ million or above. They do not compare the internal control quality of banks and non-banks.

${ }^{15}$ Throughout the paper, we omit firm and year subscripts for simplicity.
} 
liabilities to total assets (LEVERAGE). We control for clients' organizational changes associated with business acquisitions using the ratio of goodwill to total assets (GOODWILL) and an indicator variable that equals one when goodwill increases by more than $\$ 1$ million $(M \& A)$. We control for other determinants of audit complexity using the proportion of foreign sales for control firms and the proportion of foreign commercial loans for banks (FOREIGN), the ratio of market value of equity to book value of equity $(M T B)$, an indicator variable for the auditor rendering a going-concern opinion (GOING_CONCERN), and Y_CONTROL.

Because the effects of client size may be nonlinear, in some models we include indicator variables for client total assets in the following categories: up to $\$ 10$ billion (this indicator is omitted and thus serves as the base case), from above $\$ 10$ billion to $\$ 50$ billion (B10_50), from above $\$ 50$ billion to $\$ 100$ billion (B50_100), from above $\$ 100$ billion to $\$ 500$ billion (B100_500), and above $\$ 500$ billion (B500). Moreover, because the effects of size may vary for banks versus control firms, we also include the interactions of these size indicators with BANK.

We also control for three auditor characteristics: an indicator for December fiscal year end (BUSY_MONTH), an indicator variable for Big-Four auditor (BIG4), and the auditor's market share in the industry (ISPEC). Lastly, we include fixed year effects to capture unobserved time-related factors for both clients and auditors.

\subsection{Audit Effort}

We test Hypothesis 2 using two dependent variables that prior research uses as proxies for auditor effort: audit fees (Simunic and Stein 1996) and audit report lag (Ashton et al. 1987; Bamber et al. 1993; and Ghosh and Tang 2015). LogFEE denotes the natural logarithm of the sum of audit and audit-related fees. Auditors working more hours is positively associated with 
audit report lags (Bronson et al. 2011). LogREPORT_LAG denotes the natural logarithm of one plus the number of days between the fiscal year end and the audit report signature date.

Based on prior models for audit fees (e.g., Simunic 1980; Ghosh and Tang 2015), we use the following model to explain LogFEE:

$$
\begin{aligned}
\text { LogFEE } & =\beta_{0}+\beta_{1} \text { BANK }+\beta_{2} \text { LogASSETS }+\beta_{3} R O A+\beta_{4} L O S S+\beta_{5} \text { SPECIAL_ITEMS } \\
& +\beta_{6} \text { DISCONTINUED }+\beta_{7} L E V E R A G E+\beta_{8} I N V E N T O R Y+\beta_{9} I N T A N G I B L E S \\
& +\beta_{10} G O O D W I L L+\beta_{11} M \& A+\beta_{12} N E G \_E Q U I T Y+\beta_{13} F I R M \_A G E \\
& +\beta_{14} \text { ACCEL_FILER }+\beta_{15} I N T E R N A L \_W E A K N E S S+\beta_{16} M T B+\beta_{17} R E T U R N \\
& +\beta_{18} S T D \_R E T U R N+\beta_{19} \text { GOING_CONCERN }+\beta_{20} B U S Y \_M O N T H \\
& +\beta_{21} \text { BIG4 }+\beta_{22} I S P E C+\text { year fixed effects. }
\end{aligned}
$$

Based on prior models for audit report lag (Ashton et al. 1987; Bamber et al. 1993; Bronson et al. 2011; Ghosh and Tang 2015), we use the following model to explain LogREPORT_LAG:

$$
\begin{aligned}
& \text { LogREPORT_LAG }=\beta_{0}+\beta_{1} B A N K+\beta_{2} \text { LogASSETS }+\beta_{3} R O A+\beta_{4} L O S S \\
& +\beta_{5} \text { DISCONTINUED }+\beta_{6} \text { EXTRA_ITEMS }+\beta_{7} \text { ABS_ACCRUALS } \\
& +\beta_{8} L E V E R A G E+\beta_{9} I N V E N T O R Y+\beta_{10} \text { FOREIGN }+\beta_{11} \text { FIRM_AGE } \\
& +\beta_{12} \text { INTERNAL_WEAKNESS }+\beta_{13} \text { AUDITOR_TURNOVER } \\
& +\beta_{14} G O I N G \_C O N C E R N+\beta_{15} B U S Y \_M O N T H+\beta_{16} B I G 4 \\
& + \text { year fixed effects. }
\end{aligned}
$$

As in equation (1), the main test variable in equations (2) and (3) is BANK. Hypothesis 2 predicts that the coefficient $\beta_{1}$ on $B A N K$ is negative in both equations.

Equations (2) and (3) control for numerous client and auditor characteristics that prior research finds are associated with audit fees or audit report lag, respectively. Many of the control variables included in Equations (2) and (3) also appear in Equation (1) and are defined above. Equation (2) and/or equation (3) include the following additional client characteristics. ${ }^{16}$ Special items divided by total assets (SPECIAL_ITEMS), an indicator for absolute value of discontinued operations above $\$ 1$ million (DISCONTINUED), and an indicator for absolute value of

${ }^{16}$ The sets of control variables in equations (2) and (3) are not identical, consistent with the models estimated in prior research. 
extraordinary items above $\$ 1$ million (EXTRA_ITEMS) capture transitory earnings items. The absolute value of accruals divided by total assets (ABS_ACCRUALS) captures other dimensions of earnings quality. The ratio of inventory to total assets (INVENTORY) and the ratio of intangible assets to total assets (INTANGIBLES) capture balance sheet composition. An indicator for negative common equity (NEG_EQUITY) and the number of years the firm is listed on Compustat (FIRM_AGE) capture early-stage or otherwise risky firms. An indicator for accelerated filer (ACCEL_FILER) and an indicator for auditor turnover during the year (AUDITOR_TURNOVER) capture other auditing stresses. Fiscal year stock return (RETURN) and the standard deviation of monthly stock returns (STD_RETURN) capture the aggregate level and the volatility, respectively, of exogenous shocks occurring during the fiscal year.

As for equation (1), in some models we include indicator variables for client total assets in the various size categories, and we also include the interactions of these size indicators with BANK.

\subsection{Types of Earnings Management of Minor Concern to Bank Regulators and Supervisors}

We expect bank regulators and supervisors to be relatively unconcerned about certain types of earnings management that accumulate to relatively small amounts of retained earnings. Such earnings management has minor effects on banks' solvency ratios and so should not appreciably affect supervisors' evaluations of banks' safety and soundness. We further expect that, if bank regulation and supervision lead to lower audit effort in audits of banks than in audits of control firms, as predicted in Hypothesis 2, banks engage more in these types of earnings management than do control firms.

Motivated by Burgstahler and Dichev (1997), Beatty et al. (2002), and Graham et al. (2005), we examine two proxies for such earnings management: the frequency of small (from 0 
to 0.01$)$ increases in return on equity $\left(S M A L L_{-} P O S\right)^{17}$; and the length of the longest string of consecutive earnings increases for each firm (STRING). We conjecture that these types of earnings management accumulate to relatively small amounts of retained earnings. While we are unaware of any supporting empirical evidence for this conjecture, it is consistent with the absence of any mention of these types of earnings management in bank supervisory manuals, including the portions devoted to the evaluation of earnings quality (Comptroller of the Currency 2007, p. 53; Board of Governors of the Federal Reserve System 2017, §4020.3). ${ }^{18}$

Following Beatty et al. (2002), we use the following logistic model to explain SMALL_POS:

$$
\begin{aligned}
& \operatorname{Prob}\left(S M A L L \_P O S=1\right)=\mathrm{e}^{\mathrm{X} \beta} /\left(1+\mathrm{e}^{\mathrm{X} \beta}\right) \text {, where } \\
& \begin{aligned}
\mathrm{X} \beta= & \beta_{0}+\beta_{1} B A N K+\beta_{2} L O g A S S E T S+\beta_{3} L E V E R A G E+\beta_{4} M T B \\
& +\beta_{5} A C C E L \_F I L E R+\beta_{6} B I G 4+\text { year fixed effects. }
\end{aligned}
\end{aligned}
$$

We expect the coefficient $\beta_{1}$ on BANK to be positive.

Again following Beatty et al. (2002), we use the following Cox proportional hazard model to explain STRING:

$$
\begin{aligned}
& h(\text { STRING } \mid X)=\mathrm{h}_{0}(\text { STRING }) \mathrm{e}^{X \beta}, \text { where } \\
& \begin{array}{l}
X \beta=\beta_{0}+\beta_{1} \text { BANK }+\beta_{2} L o g A S S E T S+\beta_{3} L E V E R A G E+\beta_{4} M T B+\beta_{5} A C C E L \_F I L E R \\
\quad+\beta_{6} \text { INTERNAL_WEAKNESS }+\beta_{7} B I G 4+\text { year fixed effects. }
\end{array}
\end{aligned}
$$

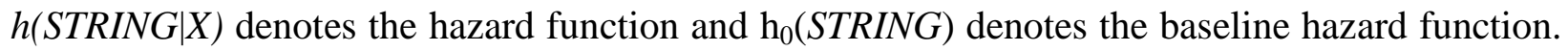

We expect the coefficient $\beta_{1}$ on BANK to be positive.

\footnotetext{
${ }^{17}$ Specifically, we compute return on equity (ROE) as net income divided by the book value of common equity. SMALL_POS takes a value of one if the change in ROE is greater than zero but smaller than or equal to 0.01 and zero otherwise.

${ }^{18}$ A side benefit of our use of these earnings management measures is that they are applied as naturally to banks as to non-banks. In contrast, the most commonly used measures of earnings management in the literature (Jones 1991; Dechow and Dichev 2002) are not naturally applied to banks.
} 
A large empirical literature documents these types of earnings management and their capital market consequences for public firms in general and for public banks in particular (Burgstahler and Dichev 1997; Beatty et al. 2002; Bartov et al. 2002; Brown and Caylor 2005). Based on this literature, we expect these types of earnings management to significantly influence banks' investors and contracting parties.

\section{Data and Sample Selection}

\subsection{Data}

We obtain audit fee, audit report signature date, auditor change, internal control weakness, and restatement data from Audit Analytics. We obtain financial statement data from Compustat's annual Bank and North American files. We obtain geographic and foreign segment data from Compustat's Segment file. If a given firm-year is available in Compustat's Bank file, we classify the firm-year observation as a bank.

Our sample covers the fifteen-year period from 2000 to 2014. The sample period begins in 2000, because audit fees are unavailable prior to that year. Because SOX-mandated internal control weakness data become available in 2004, our analysis of internal control weaknesses is limited to the eleven-year period 2004-2014. We restrict the sample to firm-year observations with complete data on audit fees, auditor identification, and audit report signature date from Audit Analytics and other financial variables from Compustat. These data requirements yield 7,775 bank-year observations (962 unique banks), 661 firm-year observations in SIC 61 (103 unique firms), and 3,107 firm-year observations in the top five percent of the ratio of accounts receivable to total assets (813 unique firms) in 2000-2014. The internal control weakness sample includes 5,465 bank-year observations, 473 firm-year observations for the SIC 61 control 
sample, and 2,252 firm-year observations for the top five percent of the ratio of accounts receivable to total assets control sample in 2004-2014.

\subsection{Descriptive Statistics}

Table 1 reports means for each of the dependent variables (above the line) and each of the independent variables (below the line) in equations (1)-(5) for the bank sample, SIC 61 control sample, and highest 5\% ratio of accounts receivable to assets control sample. Significant differences of the means for the bank sample versus the SIC 61 control sample and for the bank sample versus the highest $5 \%$ ratio of accounts receivable to assets control sample are indicated in the columns for the control samples.

The differences of the means for the dependent variables are uniformly significant and consistent with our hypotheses that banks exhibit fewer internal control and accounting problems than do control firms as well as our expectations that banks engage in more of certain types of earnings management than do control firms. Consistent with Hypothesis 1, banks are less likely to disclose material internal control weaknesses (INTERNAL_WEAKNESS) and to restate their financial statements (ACC_RESTATEMENT) than are both control samples. Consistent with Hypothesis 2, on average audit fees (FEE) are lower and audit report lags (REPORT_LAG) are shorter for banks than for both control samples. Consistent with our expectations for earnings management, banks are more likely to report small positive earnings changes (SMALL_POS) and on average report longer strings of positive earnings (STRING).

Most of the differences of the means for the independent variables are also significant. For most of these variables, the means for banks are closer to those of the a priori more analogous SIC 61 control sample than to those of the highest 5\% ratio of accounts receivable to assets control sample. Accordingly, we discuss only the former mean differences. Compared to 
the SIC 61 control sample, on average banks: are smaller (ASSETS); are more profitable (ROA) and have fewer losses (LOSS); have lower transitory earnings items (SPECIAL_ITEMS, DISCONTINUED, and EXTRA_ITEMS) and absolute accruals (ABS_ACCRUALS); have higher financial leverage (LEVERAGE); have lower non-financial assets (INVENTORY, INTANGIBLES, and GOODWILL); engage in more mergers and acquisitions $(M \& A)$; are less likely to have negative equity (NEG_EQUITY) or foreign operations (FOREIGN); have insignificantly different age (AGE); have lower expected growth (MTB); experience lower exogenous shocks (RETURN and STD_RETURN); and receive fewer going-concern opinions (GOING_CONCERN).

Compared to the SIC 61 control sample, on average banks are more likely to have December fiscal year-ends (BUSY_MONTH). However, on average banks are less likely to be accelerated filers (ACCEL_FILER); are less likely to be audited by a Big 4 auditor (BIG4); are less likely to have auditors with high relative industry market share (ISPEC); and experience less auditor turnover (AUDITOR_TURNOVER).

\section{Empirical Results}

\subsection{Frequencies of Internal Control and Accounting Problems}

Hypothesis 1 predicts that, owing to bank regulation and supervision, banks exhibit fewer internal control and accounting problems than do similar unregulated firms. To test this hypothesis, Tables 2 and 3 report logistic estimations of equation (1) with the dependent variables INTERNAL_WEAKNESS and ACC_RESTATEMENT, respectively. ${ }^{19}$ We report the estimation of each model for the combined bank sample and SIC 61 control sample in the left

\footnotetext{
${ }^{19}$ In untabulated analyses, we also examine adverse restatements that reduce owners' equity and auditor resignations. We find results consistent with those reported in the paper.
} 
column of the table and for the combined bank sample and highest 5\% ratio of accounts receivable to assets control sample in the right column of the table.

We estimate each model in two different ways. Panel A of each table reports the estimation of the base model. To better control for size differences between the bank and control samples, Panel B of each table reports estimations of the equations replacing LogASSETS with the client size category indicators (B10_50, B50_100, B100_500, and B500) both separately and interacted with BANK. The coefficient on BANK equals the effect for the smallest banks (assets less than $\$ 10$ billion) incremental to the effect for the smallest control firms; we call this incremental effect $X$. The coefficient on the interaction of BANK with a given size category indicator equals the effect for the banks in that size category incremental to the effect for the control firms in that size category—call this incremental effect $Y$ —minus the incremental effect $X$. The sum of the coefficients on BANK and on the interaction of BANK with a given size category indicator equals the incremental effect $Y$.

The model fits and the coefficients on the control variables generally are as expected based on prior research. For simplicity, we primarily discuss the statistical and economic significance of the coefficient $\beta_{1}$ on BANK estimated on the combination of the bank sample and the more analogous SIC 61 control sample reported in the left column of Panel A of the tables. We point out any notable differences in the results for the other models. All these differences pertain to the coefficients on BANK and the interactions of BANK with the size category indicators in Panel B; when they exist, these differences indicate that the effects we document are limited to certain size categories. In particular, no notable differences arise from the use of different control samples in the estimations reported in the left and right columns of the tables. In 
discussing economic significance, we focus on $e^{\beta_{1}}$, the differential frequency of internal control and accounting problems for banks versus non-banks.

In the estimation of equation (1) with dependent variable INTERNAL_WEAKNESS reported in the left column of Panel A of Table 2, the coefficient on BANK is negative $(-0.382)$ and significant at the $1 \%$ level. This coefficient implies that banks disclose material internal control weaknesses with only $68 \%$ of the likelihood of SIC 61 control firms, controlling for other factors that prior research finds are associated with internal control weaknesses. These results are consistent with Hypothesis 1 that bank regulation and supervision reduce the frequency of banks’ internal control problems.

In the left column of Panel B of Table 2, the coefficient on BANK is negative as expected but insignificant. Notice, however, that the coefficients on the interactions of BANK with all of the size category indicators are also negative, with these coefficients being significant at the $1 \%$ for the interaction of BANK with B10_50. The sum of the coefficients on BANK and $B A N K \times B 10 \_50$ is significantly negative at the $1 \%$ level and the sum of the coefficients on BANK and BANK $\times$ B50_100 is significantly negative at the $10 \%$ level. These results imply that banks with assets from $\$ 10$ billion to $\$ 100$ billion disclose significantly fewer internal control weaknesses than do similar-size control firms, consistent with Hypothesis 1, whereas banks in other size categories disclose internal control weaknesses with insignificantly different frequency than do similar-size control firms.

In the estimation of equation (1) with dependent variable ACC_RESTATEMENT reported in the left column of Panel A of Table 3, the coefficient on BANK is negative (-0.527) and significant at the $1 \%$ level. This coefficient implies that banks file financial statement restatements with only 59\% of the likelihood of SIC 61 control firms, controlling for other 
factors that prior research finds are associated with restatements. These results are consistent with Hypothesis 1 that bank regulation and supervision reduce the frequency of banks' accounting problems.

In the left column of Panel B of Table 3, the coefficient on BANK is negative as expected but insignificant. The coefficients on the interactions of BANK with all of the size category indicators are again negative, but only the coefficient on the interaction of BANK with B10_50 is significant at the $5 \%$ level. The sum of the coefficients on BANK and its interaction with B10_50 is significantly negative at the $1 \%$ level and the sum of the coefficients on BANK and its interaction with B100_500 is significantly negative at the $10 \%$ level. These results imply that banks with assets from $\$ 10$ billion to $\$ 50$ billion and those with assets from $\$ 100$ billion to $\$ 500$ billion report significantly fewer accounting restatements than similar-size control firms, consistent with Hypothesis 1, whereas banks in other size categories report accounting restatements with insignificantly different frequency.

Collectively, the results reported in Tables 2 and 3 for disclosed material internal control weaknesses and accounting restatements are consistent with bank regulation and supervision rendering engagements for audits banks less risky than for audits of control firms for some size categories, and insignificantly differently risky for other size categories.

\subsection{Audit Effort}

Hypothesis 2 predicts that bank regulation and supervision lead bank auditors to expend less effort. We proxy for (lower) audit effort using (lower) audit fees and (shorter) audit report lags. To test this hypothesis, Table 4 reports OLS estimations of equation (2) that explain the natural logarithm of audit fees (LogFEE), while Table 5 reports OLS estimations of equation (3) that explain the natural logarithm of the number of days between the fiscal year end and the audit 
report signature date (LogREPORT_LAG). The structures of Tables 4 and 5 are the same as those of Tables 2 and 3. The left columns of the tables report the estimations for the combined bank sample and SIC 61 control sample. The right columns of the tables report the estimations for the combined bank sample and highest 5\% ratio of accounts receivable to assets control sample. Panel A of the tables report the estimation of the base model and Panel B of the tables report the estimation of the models that include the size category indicators both separately and interacted with BANK. The model fits and the coefficients on the control variables again generally are as expected based on prior literature, so we discuss only the statistical and economic significance of the coefficients $\beta_{1}$ on BANK in Panel A and of the coefficients on BANK and the interactions of BANK with the size category indicators in Panel B.

In the estimation of equation (2) with dependent variable LogFEE reported in the left column of Panel A of Table 4, the coefficient on BANK is negative (-0.711) and significant at the $1 \%$ level. This coefficient implies that on average audit fees for banks are only 51\% of that for SIC 61 control firms, controlling for other factors that prior research finds are associated with audit fees. These results are consistent with Hypothesis 2's prediction that bank regulation and supervision lead to reduced audit effort.

In both columns of Panel B of Table 4, the coefficient on BANK is significantly negative as expected. However, the coefficient on the interactions of BANK with the largest size category B500 is significantly positive and of similar absolute magnitude as the coefficient on BANK. As a result, the coefficient on the sum of BANK and its interaction with B500 is insignificantly different from zero, whereas the sum of the coefficients on BANK and its interactions with each of the other size indicators is significantly negative. These results imply that, relative to similar- 
size control firms, audit effort is lower for banks with assets up to $\$ 500$ billion, and audit effort is insignificantly different for banks with assets above $\$ 500$ billion.

The latter result suggests that bank regulation and supervision do not displace bank auditing for the (relatively few and highly complex) largest banks. There are at least two possible explanations for this result for future research to distinguish. One is that bank regulation and supervision are less effective for these banks. Bank regulators have long recognized the difficulty of regulating the largest banks, which the Federal Reserve refers to as "large, complex banking organizations” (Meyer 2000; Eisenbach et al. 2017). Another explanation is that large banks' opacity and economic importance provide sufficient incentive for their auditors to expend appropriate levels of effort.

In the estimation of equation (2) with dependent variable LogREPORT_LAG reported in the left column of Panel A of Table 5, the coefficient on BANK is negative $(-0.089)$ and significant at the $1 \%$ level. This coefficient implies that on average audit report lag for banks is only $90 \%$ of that for SIC 61 control firms, controlling for other factors that prior research finds are associated with audit report lag. These results are consistent with Hypothesis 2 that bank regulation and supervision lead to reduced audit effort.

In both columns of Panel B of Table 5, the coefficient on BANK is significantly negative as expected. However, the coefficients on the interaction of BANK with all of the size categories are positive, often significantly so, and of similar absolute magnitude as the coefficient on $B A N K$. As a consequence, none of the sums of the coefficients on BANK and its interactions with the size category indicators is significant. These results imply that, relative to similar-size control firms, audit effort is lower and thus audit report lag is shorter for banks with assets up to $\$ 10$ billion, and audit report lag is insignificantly different for banks with assets above $\$ 10$ billion. 
A possible alternative explanation for the audit effort results reported in Tables 4 and 5 is that bank auditors exert less audit effort because they have developed bank client-specific expertise through longer average tenure in bank audit engagements (Gul, Fung, and Jaggi 2009). In addition, the audit fee results reported in Table 4 could reflect fee discounts offered to new bank audit engagements (DeAngelo 1981). In untabulated analysis, we ruled out both of these alternative explanations by partitioning the sample into three groups based on audit engagement tenure: less than five years, five to ten years, and beyond ten years. In each tenure group, we find lower audit effort for audits of banks than for audits of control firms.

Collectively, the audit fee and audit report lag estimation results reported in Tables 4 and 5 provide evidence consistent with bank regulation and supervision leading auditors to expend lower audit effort on audits of banks in certain size categories.

\subsection{Identification Tests for Audit Effort Models}

To provide support for bank regulation and supervision as causally explaining the reduced audit effort in bank audits documented in Tables 4 and 5, we estimate expansions of the audit-fee model (equation (2)) and the audit-report-lag model (equation (3)) that include timeseries and cross-sectional proxies for the intensity of bank regulation. Consistent with the arguments leading to Hypothesis 2 in Section 2.3.3, we predict that bank audit effort is lower when bank regulatory intensity is higher. As the inferences generated by our tests of this prediction are similar for the two expanded models, for brevity, we tabulate and discuss only the results for the expanded audit fee model.

Table 6 reports OLS estimations of equation (2) with LogFEE as the dependent variable expanded to include one of two time-series measures of bank regulation intensity. The sample is limited to 7,775 bank-year observations (962 unique banks) from 2000 to 2014, so BANK is 
dropped from the equation. The first time-series bank regulation intensity measure is based on RegData, an industry- and year-specific regulation index constructed by Al-Ubaydli and McLaughlin (2017) from textual analysis of the number of constraints (the strings "shall," "must," "may not," "prohibited," and "required”) in the Code of Federal Regulations (CFR). This measure is the natural logarithm of the number of constraints in CFR Title 12 for the banking industry each year (LogRESTRICTIONS). The second time-series measure is the natural logarithm of the annual budget (in \$ millions) of the "finance and banking” subcategory (which includes the Comptroller of the Currency, Federal Deposit Insurance Corporation, and Securities and Exchange Commission) from Regulatory Reports available at https://wc.wustl.edu/regulatory_reports (LogBUDGET). Figure 1 depicts the evolutions of LogRESTRICTIONS and LogBUDGET from 2000-2014. Panel A of Table 6 reports descriptive statistics of the two measures of bank regulation intensity.

The left (right) column of Table 6 reports the estimation of equation (2) adding LogBUDGET (LogRESTRICTIONS) to the model. The coefficients on LogBUDGET and LogRESTRICTIONS are both significantly negative at the $1 \%$ level, consistent with more intense bank regulation leading to lower audit effort and thus lower audit fees.

Table 7 reports the OLS estimations of equation (2) with LogFEE as the dependent variable that include Agarwal et al.'s (2014) measure of regulatory leniency (i.e., inverse intensity) across state-chartered banks (STATE_REG). This measure is based on the "alternating examination program” in which state-chartered banks are examined by (more stringent) federal supervisors (the FDIC or Federal Reserve) and state supervisors in rotation. Using a proprietary database, Agarwal et al. (2014) estimate the differential examination stringency of federal supervisors versus 44 state supervisors. The left column reports the estimation of a model that 
includes STATE_REG linearly. This model is estimated on 5,597 state bank-year observations (737 unique banks) from 2000 to 2014. The right column reports the estimation of a model that includes STATE_REG both linearly and interacted with an indicator for state-chartered banks $\begin{array}{llll}\left(S T A T E \_B A N K\right) & \text { obtained } & \text { from } & \text { FDIC }\end{array}$ (https://www5.fdic.gov/idasp/advSearchLanding.asp). This model is estimated using 7,228 (federal and state) bank-year observations (902 unique banks) from 2000 to 2014. The coefficient on STATE_REG in the left column and the coefficient on STATE_REG $\times S T A T E \_B A N K$ in the right column of the table are both significant positive at the 5\% level, consistent with more lenient state regulation yielding higher audit effort and thus higher audit fees.

Overall, the expanded audit fee model estimation results reported in Tables 6 and 7 provide evidence consistent with the intensity of bank regulation and supervision causally explaining the extent of the reduced audit effort in bank audits reported in Tables 4 and 5 .

\subsection{Types of Earnings Management of Minor Concern to Bank Regulators and Supervisors}

As discussed in Section 3.3, if bank regulation and supervision lead to lower audit effort, banks should have more ability to exercise accounting discretion to manage accounting numbers in ways that do not significantly concern bank regulators and supervisors. We examine two types of earnings management that we expect to be of minor concern to bank regulators and supervisors: the frequency of small positive earnings (SMALL_POS) and the length of the longest string of consecutive earnings increases (STRING).

To test for differences in SMALL_POS for banks versus the firms in the control samples, Table 8 reports the logistic estimation of equation (4) with SMALL_POS as the dependent variable for the combined BANK sample and SIC 61 control sample (left column) and for the 
combined BANK sample and highest $5 \%$ ratio of accounts receivable to assets control sample (right column). A positive coefficient $\beta_{1}$ on $B A N K$ implies that banks exhibit more frequent small positive earnings changes than do control firms, consistent with bank regulation and supervision leading to lower audit effort in audits of banks. In both columns, the coefficient on BANK is significantly positive at the $1 \%$ level. The coefficient in the left (right) column implies that banks report small positive earnings 4.3 (3.9) times as frequently as the corresponding control firms, controlling for other variables that prior research shows are associated with the frequency of small positive earnings.

To test for differences in STRING for banks versus control firms, Table 9 reports the estimation of equation (3) using the Cox proportional hazard approach for the combined BANK sample and SIC 61 control sample (left column) and for the combined BANK sample and highest $5 \%$ ratio of accounts receivable to assets control sample (right column). The Cox proportional hazard approach accounts for the right-censoring of STRING arising from our sample ending in 2014. A positive coefficient $\beta_{1}$ on BANK implies that banks exhibit earnings strings with incrementally longer length than do control firms, consistent with bank regulation and supervision leading to lower bank audit effort, enabling banks to exercise accounting discretion to sustain earnings strings. In both columns, the coefficient on BANK is significantly positive at the $1 \%$ level. The coefficient in the left (right) column implies that banks report strings of positive earnings that are $45 \%$ (95\%) longer than the corresponding control firms, controlling for other variables that prior research shows are associated with the length of earnings strings.

Collectively, the results reported in Tables 8 and 9 indicate that, compared to control firms, banks are more likely to engage in certain types of earnings management that are likely to 
be of minor concern to bank regulators and supervisors. These results are consistent with bank regulation and supervision leading to lower audit effort in audits of banks.

\section{Conclusion}

Banks are regulated and supervised under extensive banking laws and regulations. Moreover, bank supervision involves periodic on-site examination and off-site monitoring activities that overlap considerably with auditing activities. In this study, we examine whether bank regulation and supervision displace bank auditing, leading to lower audit effort in audits of banks than in audits of two control samples of similar unregulated firms: (1) non-depository credit institutions (two-digit SIC code 61) and (2) all non-banks in the highest five percent of the ratio of accounts receivable (which includes loan and lease receivables) to total assets. Our results are consistent with bank regulation and supervision displacing auditing, i.e., with audit effort being significantly lower in audits of banks than in audits of control firms.

We first provide evidence that banking engagements pose less risk to auditors. We show that banks are significantly less likely than control firms to disclose material weaknesses in internal controls and to restate their financial statements, controlling for variables previously shown to be associated with material internal control weaknesses and restatements. We then provide evidence consistent with auditors exerting less effort on audits of banks than on audits of control firms. We show that bank audits exhibit statistically and economically lower audit fees and shorter audit report lags than do audits of control firms, controlling for the variables that prior research shows to be associated with audit fees and audit report lags.

We acknowledge that the primary threat to inference in our study is the possibility that factors other than bank regulation and supervision explain why audits of banks pose less audit risk than do audits of control firms. Although we cannot rule out this possibility altogether, we 
conduct two sets of tests to provide support for the conclusion that the associations we document are causal. First, we provide evidence that bank auditors expend less effort when bank regulation and supervision are more intense. We use two time-series measures based on the text of banking regulations and the annual budget of federal regulators and one cross-sectional measure based on Agarwal et al. (2014) of the intensity of bank supervision. Second, we provide evidence that banks are more likely to engage in two types of earnings management that are of minor concern to bank regulators and supervisors but that prior research shows have capital market consequences. We find that banks report more frequent small positive earnings and longer strings of earnings increases than do similar firms.

We contribute to the banking and auditing literatures by providing evidence consistent with auditors expending less effort in auditing banks than in auditing control firms, owing to the overlap of the activities of bank regulators and supervisors with those of auditors. We emphasize that our evidence does not suggest that the aggregate monitoring of banks’ financial reporting by bank regulators, supervisors, and auditors differs from the monitoring of similar firms’ financial reporting by auditors alone, it only suggests that the monitoring conducted by bank auditors is less. Because of the importance of banks to financial system stability and macroeconomic health, a compelling question is what incremental costs arise when bank auditors, as financial reporting specialists, expend less effort on bank audits due to the existence of bank regulation and supervision. We provide evidence that this reduced audit effort leads to types of earnings management that likely have minor effects on banks' solvency ratios but have capital market consequences documented by prior research that may lead to reduced market discipline over banks. We expect these results to be of interest to bank and auditing policymakers. 


\section{References}

Acharya, V., and S. Ryan. 2016. Banks' financial reporting and financial system stability. Journal of Accounting Research 54: 277-340.

Acharya, V. 2014. A transparency standard for derivatives. Chapter 6 in Risk Topography: Systematic Risk and Macro Modeling, edited by M. Brunnermeier and A. Krishnamurthy, National Bureau of Economic Research, University of Chicago Press 2014.

Agarwal, S., D. Lucca, A. Seru, and F. Trebbi. 2014. Inconsistent regulators: Evidence from banking. Quarterly Journal of Economics 129: 889-938.

Altamuro, J., and A. Beatty. 2010. How does internal control regulation affect financial reporting? Journal of Accounting and Economics 49: 58-74.

Al-Ubaydli, O., and P. McLaughlin. 2017. RegData: A numerical database on industry-specific regulations for all United States industries and federal regulations, 1997-2012. Regulation \& Governance 11: 109-123.

Ashbaugh-Skaife, H., D. Collins, and W. Kinney Jr. 2007. The discovery and reporting of internal control deficiencies prior to SOX-mandated audits. Journal of Accounting and Economics 44: 166-192.

Ashton, R., J. Willingham, and R. Elliot. 1987. An empirical analysis of audit delay. Journal of Accounting Research 25: 275-292.

Avraham, D., P. Selvaggi, and J. Vickrey. 2012. A structural view of US bank holding companies. Federal Reserve Bank of New York Economic Policy Review 18: 65-81.

Badertscher, B., J. Burks, and P. Easton. 2016. The market reaction to bank regulatory filings. Working paper, University of Notre Dame.

Bamber, E., L. Bamber, and M. Schoderbek. 1993. Audit structure and other determinants of audit report lag: An empirical analysis. Auditing: A Journal of Practice and Theory 12: 123.

Barth, M., and W. Landsman. 2010. How did financial reporting contribute to the financial crisis? European Accounting Review 19: 399-433.

Barth, J., T. Li, and W. Lu. 2009. Bank regulation in the United States. CESifo Economic Studies 10: 2-29.

Bartov, E., D. Givoly, and C. Hayn. 2002. The rewards to meeting or beating earnings expectation. Journal of Accounting and Economics 33 (2): 173-204. 
Beatty, A., B. Ke, and K. Petroni. 2002. Earnings management to avoid earnings declines across publicly and privately held banks. The Accounting Review 77: 547-570.

Beatty, A., and S. Liao. 2014. Financial accounting in the banking industry: A review of the empirical literature. Journal of Accounting and Economics 58: 339-383.

Bedard, J., and K. Johnstone. 2004. Earnings manipulation risk, corporate governance risk, and auditors’ planning and pricing decisions. The Accounting Review 79: 277-304.

Bell, T., W. Landsman, and D. Shackelford. 2001. Auditors' perceived business risk and audit fees: Analysis and evidence. Journal of Accounting Research 39: 35-43.

Board of Governors of the Federal Reserve Board System. 2017. Bank Holding Company Supervision Manual, Division of Banking Supervision and Regulation, https://www.federalreserve.gov/publications/supervision_bhc.htm.

Bronson, S., C. Hogan, M. Johnson, and K. Ramesh. 2011. The unintended consequences of PCAOB auditing standard nos. 2 and 3 on the reliability of preliminary earnings releases. Journal of Accounting and Economics 51: 95-114.

Brown, L., and M. Caylor. 2005. A temporal analysis of quarterly earnings thresholds: Propensities and valuation consequences. The Accounting Review 80 (2): 423-440.

Burgstahler, D., and I. Dichev. 1997. Earnings management to avoid earnings decreases and losses. Journal of Accounting and Economics 24: 99-126.

Comptroller of the Currency. 2007 (last updated 2017). Bank supervision process: Comptroller’s handbook.

Costello, A., J. Granja, and J. Weber. 2016. Do strict regulators increase the transparency of the banking system? Working paper, Massachusetts Institute of Technology.

Dang, T., G. Gorton, B. Holmström, and Ordoñez, G. 2014. Banks as secret keepers. PIER working paper no. 14-022.

DeAngelo, L. 1981. Auditor independence, “low balling”, and disclosure regulation. Journal of Accounting and Economics 3: 113-127.

Dechow, P., and I. Dichev. 2002. The quality of accruals and earnings: The role of accrual estimation errors. The Accounting Review 77: 35-59.

DeFond, M., and J. Zhang. 2014. A review of archival auditing research. Journal of Accounting and Economics 58: 275-326. 
Diamond, D. 1984. Financial intermediation and delegated monitoring. Review of Economic Studies 51: 393-414.

Doyle, J., W. Ge, and S. McVay. 2007a. Accruals quality and internal control over financial reporting. The Accounting Review 82: 1141-1170.

Doyle, J., W. Ge, and S. McVay. 2007b. Determinants of weaknesses in internal control over financial reporting. Journal of Accounting and Economics 44: 193-223.

Eisenbach, T., A Haughwout, B. Hirtle, A. Kovner, D. Lucca, and M. Plosser. 2017. Supervising large, complex banking institutions: What do supervisors do? FRBNY Economic Policy Review February: 57-77.

Flannery, M., S. Kwan, and M. Nimalendran. 2013. The 2007-2009 financial crisis and bank opaqueness. Journal of Financial Intermediation 22: 55-84.

Gallemore, J. 2016. Bank financial reporting opacity and regulatory intervention. Working paper, University of Chicago.

Ge, W., and S. McVay. 2005. The disclosure of material weaknesses in internal control after the Sarbanes-Oxley Act. Accounting Horizons 19: 137-158.

Ghosh, A., and C. Tang. 2015. Assessing financial reporting quality of family firms: The auditors’ perspective. Journal of Accounting and Economics 60: 95-116.

Graham, J., C. Harvey, and S. Rajgopal. 2005. The economic implications of corporate financial reporting. Journal of Accounting and Economics 40: 3-73.

Guay, W., D. Samuels, D. Taylor. 2016 Guiding through the fog: Financial statement complexity and voluntary disclosure. Journal of Accounting and Economics 62: 234-269.

Gul, F., S. Fung, and B. Jaggi. 2009. Earnings quality: Some evidence on the role of auditor tenure and auditors' industry expertise. Journal of Accounting and Economics 47: 265287.

Hennes, K., A. Leone, and B. Miller. 2014. Determinants and market consequences of auditor dismissals after accounting restatements. The Accounting Review 89: 1051-1082.

Holmström, B. 2015. Understanding the role of debt in the financial system. BIS working paper no. 479.

Houston, R., M. Peters, and J. Pratt. 1999. The audit risk model, business risk and audit-planning decisions. The Accounting Review 74: 281-298. 
Jensen, M., and W. Meckling. Theory of the firm: Managerial behavior, agency costs and ownership structure. Journal of Financial Economics 3: 305-360.

Jones, J. 1991. Earnings management during import relief investigations. Journal of Accounting Research 29: 193-228.

Johnstone, K., A. Gramling, and L. Rittenberg. 2014. Auditing: A Risk Based Approach to Conducting a Quality Audit, $9^{\text {th }}$ edition, South-Western, Cengage Learning, Mason, $\mathrm{OH}$.

Keeley, J. 2017. The impact of regulatory enforcement on bank risk. Working paper, New York University.

Kinney, W., Palmrose, Z., and S. Scholz. 2004. Auditor independence, non-audit services, and restatements: Was the U.S. government right? Journal of Accounting Research 42: 561588.

Krishnan, J., and J. Krishnan. 1997. Litigation risk and auditor resignations. The Accounting Review 72: 539-560.

Lee, H., V. Mande, and R. Ortman. 2004. The effect of audit committee and board of director independence on auditor resignation. Auditing: A Journal of Practice and Theory 23 (2): 131-146.

Meyer, L. 2000. The challenges of global financial institutions supervision. Speech at the Federal Financial Institutions Examination Council, International Banking Conference, Arlington, Virginia, May 31.

Morgan, D. 2002. Rating banks: Risk and uncertainty in an opaque industry. The American Economic Review 92: 874-888.

Myers, S. 1977. Determinants of corporate borrowing. Journal of Financial Economics 5: 147175.

Nicoletti, A. 2016. The effects of auditors and regulators on bank financial reporting: Evidence from loan loss provisions. Doctoral dissertation, Ohio State University.

Nier, E., and U. Baumann. 2006. Market discipline, disclosure and moral hazard in banking. Journal of Financial Intermediation 15: 332-361.

Palmrose, Z, and S. Scholz. 2004. The circumstances and legal consequences of non-GAAP reporting: Evidence from restatements. Contemporary Accounting Research 21: 139-180.

Pettway, R., and J. Sinkey. 1980. Establishing on-site bank examination priorities: An earlywarning system using accounting and market information. Journal of Finance XXXV: 137-150 
Public Company Accounting Oversight Board (PCAOB). Auditing Standard No. 8: Audit Risk. Washington, D.C.: PCAOB.

Public Company Accounting Oversight Board (PCAOB). Auditing Standard No. 12: Identifying and Assessing Risks of Material Misstatement. Washington, D.C.: PCAOB.

Public Company Accounting Oversight Board (PCAOB). Auditing Standard No. 13: The Auditor's Responses to the Risks of Material Misstatement. Washington, D.C.: PCAOB.

Richardson, M., K. Schoenholtz, B. Tuckman, and L. White, eds. 2017. Regulating Wall Street: CHOICE Act vs. Dodd-Frank. New York: Center for Global Economy and Business, NYU Stern School of Business.

Ryan, S. 2007. Financial Instruments and Institutions: Accounting and Disclosure Rules. Second edition, John Wiley and Sons, Hoboken, NJ.

Ryan, S. 2011. Financial reporting for financial instruments. Foundations and Trends in Accounting 6: 187-354.

Schwartz, K., and B. Soo. 1995. An analysis of Form 8-K disclosures of auditor changes by firms approaching bankruptcy. Auditing: A Journal of Practice and Theory 14: 124-136.

Shu, S. Auditor resignations: Clientele effects and legal liability. Journal of Accounting and Economics 29: 173-205.

Simunic, D. 1980. The pricing of audit services: Theory and evidence. Journal of Accounting Research 18: 161-190.

Simunic, D., and M. Stein. 1996. The impact of litigation risk on audit pricing: A review of the economics and the evidence. Auditing: A Journal of Practice and Theory 15 (Supplement): 119-134.

Watts, R. L., and J. L. Zimmerman. 1986. Positive Accounting Theory. Prentice-Hall Inc. 
Table 1

Variable means for banks versus control firms

\begin{tabular}{|c|c|c|c|c|c|}
\hline & \multirow{3}{*}{$\begin{array}{l}\text { BANK } \\
\text { Mean }\end{array}$} & \multicolumn{4}{|c|}{ CONTROL } \\
\hline & & \multicolumn{2}{|c|}{ SIC61 } & \multicolumn{2}{|c|}{ High REC/AT } \\
\hline & & Mean & Difference & Mean & Difference \\
\hline INTERNAL_WEAKNESS & 0.025 & 0.051 & $0.027 * * *$ & 0.066 & $0.042 * * *$ \\
\hline ACC_RESTATEMENT & 0.007 & 0.023 & $0.016 * * *$ & 0.020 & $0.013 * * *$ \\
\hline FEE (\$ million) & 1.582 & 6.284 & $4.702 * * *$ & 3.109 & $1.527 * * *$ \\
\hline REPORT_LAG & 59.135 & 68.436 & $9.301 * * *$ & 68.126 & $8.991 * * *$ \\
\hline SMALL_POS & 0.174 & 0.064 & $-0.111 * * *$ & 0.063 & $-0.111 * * *$ \\
\hline STRING & 5.611 & 4.515 & $-1.097 * * *$ & 3.344 & $-2.267 * * *$ \\
\hline ASSETS (\$ billion) & 37.478 & 104.063 & $66.585 * * *$ & 30.351 & $-7.126^{*}$ \\
\hline$R O A$ & 0.006 & -0.007 & $-0.013^{*}$ & -0.007 & $-0.013 * * *$ \\
\hline LOSS & 0.106 & 0.253 & $0.147^{* * *}$ & 0.273 & $0.167 * * *$ \\
\hline SPECIAL_ITEMS & -0.001 & -0.016 & $-0.015 * *$ & -0.019 & $-0.019 * * *$ \\
\hline DISCONTINUED & 0.027 & 0.165 & $0.138 * * *$ & 0.105 & $0.077 * * *$ \\
\hline EXTRA_ITEMS & 0.011 & 0.048 & $0.037 * * *$ & 0.030 & $0.019 * * *$ \\
\hline$A B S \_A C C R U A L S$ & 0.027 & 0.093 & $0.066 * * *$ & 0.106 & $0.080 * * *$ \\
\hline LEVE $R A G E$ & 0.902 & 0.722 & $-0.179 * * *$ & 0.609 & $-0.292 * * *$ \\
\hline INVENTORY & 0.013 & 0.057 & $0.044 * * *$ & 0.071 & $0.059 * * *$ \\
\hline INTANGIBLES & 0.012 & 0.039 & $0.027 * * *$ & 0.074 & $0.061 * * *$ \\
\hline GOODWILL & 0.010 & 0.020 & $0.010 * * *$ & 0.056 & $0.047 * * *$ \\
\hline$M \& A$ & 0.197 & 0.154 & $-0.042 * * *$ & 0.229 & $0.032 * * *$ \\
\hline NEG_EQUITY & 0.002 & 0.026 & $0.023 * * *$ & 0.038 & $0.035 * * *$ \\
\hline FOREIGN & 0.039 & 0.113 & $0.075 * * *$ & 0.192 & $0.153 * * *$ \\
\hline FIRM_AGE & 14.287 & 14.844 & 0.557 & 17.971 & $3.684 * * *$ \\
\hline ACCEL_FILER & 0.626 & 0.684 & $0.057 * * *$ & 0.609 & $-0.018^{*}$ \\
\hline MTB & 1.439 & 1.698 & $0.259 * * *$ & 2.603 & $1.164 * * *$ \\
\hline RETURN & 0.107 & 0.171 & $0.064 * *$ & 0.179 & $0.071 * * *$ \\
\hline STD_RETURN & 0.083 & 0.145 & $0.062 * * *$ & 0.153 & $0.070 * * *$ \\
\hline GOING_CONCERN & 0.006 & 0.015 & $0.009 *$ & 0.027 & $0.021 * * *$ \\
\hline BUSY_MONTH & 0.879 & 0.787 & $-0.092 * * *$ & 0.716 & $-0.163 * * *$ \\
\hline$B / G 4^{-}$ & 0.441 & 0.678 & $0.237 * * *$ & 0.629 & $0.187^{* * *}$ \\
\hline ISPEC & 0.114 & 0.168 & $0.054 * * *$ & 0.161 & $0.047 * * *$ \\
\hline AUDITOR_TURNOVER & 0.073 & 0.080 & 0.008 & 0.093 & $0.020 * * *$ \\
\hline
\end{tabular}

This table reports variable means for the BANK and two CONTROL samples as well as the differences of variable means across the BANK and each CONTROL sample over the period 2000-2014. Inclusion in the BANK sample is based on inclusion in the Compustat Bank file (7,775 bank-year observations). The SIC61 sample includes non-depository credit institutions with two-digit standard industry classification (SIC) code 61 on the Compustat Annual North American file 
(661 firm-year observations). The High REC/TA control sample includes non-bank firms with a ratio of accounts receivable to total assets in the top $5 \%$ of the Compustat Annual North American file (3,107 firm-year observations). All variables are measured for a given firm-year unless indicated otherwise. The dependent variables are reported above the line in the table and are defined as follows. INTERNAL_WEAKNESS = 1 if the firm disclosed internal control deficiencies and 0 otherwise. ACC_RESTATEMENT = 1 if the firm subsequently restated its $10-K$ filing for the fiscal year and 0 otherwise. FEE = the sum of audit fees and audit-related fees in $\$$ millions. REPORT_LAG = the number of days between the fiscal year-end date and auditor signature date (the natural logarithm of this variable is used in the regression analyses). SMALL_POS $=1$ if a small ROE increase $(0.00<\triangle R O E \leq 0.01)$ is reported. $S T R I N G=$ the duration of the longest string of consecutive annual earnings increases for the firm. The control variables are reported below the line in the table and are defined as follows. ASSETS = total assets. $R O A=$ net income divided by total assets. $L O S S=1$ if the firm reports negative net income and 0 otherwise. SPECIAL_ITEMS $=$ special items divided by total assets. DISCONTINUED = 1 if discontinued operations exceeds $\$ 1$ million and 0 otherwise. EXTRA_ITEMS = 1 if (absolute) extraordinary items exceeds $\$ 1$ million and 0 otherwise. ABS_ACCRUALS = absolute value of accruals divided by total assets. $L E V E R A G E=$ total liabilities divided by total assets. INVENTORY = inventory divided by total assets. INTANGIBLES = intangibles assets divided by total assets. GOODWILL = goodwill divided by total assets. $M \& A=1$ if goodwill increases by more than $\$ 1$ million and 0 otherwise. NEG_EQUITY = 1 if common equity is negative and 0 otherwise. FOREIGN = 1 if a company reports non-zero foreign exchange income and 0 otherwise. FIRM_AGE = the number of years a company is listed in Compustat. ACCEL_FILER = 1 if the company is an accelerated filer and 0 otherwise. $M T B=$ market value of equity divided by book value of equity. RETURN = fiscal year stock return. $S T D \_R E T U R N=$ standard deviation of monthly stock returns. GOING_CONCERN = 1 if the firm received a going-concern modified opinion and 0 otherwise. $B U S Y \_M O N T H=1$ if the fiscal year-end month is December and 0 otherwise. $B I G 4=1$ if the company is audited by one of the Big-Four auditors and 0 otherwise. ISPEC = auditor's relative market share of audit fees in the client's Fama-French 48 industry classification. AUDITOR_TURNOVER = 1 if the firm's auditor changed during the year and 0 otherwise. $* * *, * *$, and $*$ denote significantly different variable means for the BANK and each CONTROL sample at the $1 \%, 5 \%$, and $10 \%$ levels, respectively. 
Table 2

Likelihood of material internal control weaknesses for banks versus control firms

\begin{tabular}{|c|c|c|c|c|}
\hline \multicolumn{5}{|c|}{$\begin{array}{r}\text { Panel A: Logistic estimation of likelihood of material internal control weaknesses } \\
\text { CONTR }\end{array}$} \\
\hline & \multicolumn{2}{|c|}{ SIC61 } & \multicolumn{2}{|c|}{ High REC/TA } \\
\hline BANK & -0.382 & $(0.002)$ & -0.271 & $(0.001)$ \\
\hline LogASSETS & 0.059 & $(0.254)$ & 0.016 & $(0.646)$ \\
\hline$R O A$ & 1.253 & (0.429) & 0.129 & $(0.736)$ \\
\hline LOSS & 0.732 & $(0.000)$ & 0.665 & $(0.000)$ \\
\hline LEVERAGE & 0.629 & (0.459) & -0.811 & $(0.018)$ \\
\hline GOODWILL & 2.904 & $(0.223)$ & 1.055 & $(0.202)$ \\
\hline$M \& A$ & 0.028 & (0.774) & 0.094 & $(0.202)$ \\
\hline FOREIGN & -0.546 & (0.174) & 0.507 & $(0.001)$ \\
\hline MTB & 0.031 & (0.517) & -0.040 & $(0.094)$ \\
\hline GOING CONCERN & 1.049 & $(0.000)$ & 0.692 & $(0.000)$ \\
\hline ACC_RESTATEMENT (Y_CONTROL) & -0.046 & $(0.900)$ & 0.129 & $(0.585)$ \\
\hline BUSY_MONTH & -0.012 & (0.915) & 0.090 & $(0.220)$ \\
\hline$B I G 4^{-}$ & -0.575 & $(0.048)$ & -0.428 & $(0.001)$ \\
\hline ISPEC & 4.001 & (0.059) & 2.153 & $(0.011)$ \\
\hline Intercept & -3.667 & (0.447) & -6.656 & $(0.002)$ \\
\hline Year fixed effects & \multicolumn{2}{|c|}{ Yes } & \multicolumn{2}{|c|}{ Yes } \\
\hline Observations & \multicolumn{2}{|c|}{5,938} & \multicolumn{2}{|c|}{7,717} \\
\hline McFadden's $\mathrm{R}^{2}$ & \multicolumn{2}{|c|}{$8.24 \%$} & \multicolumn{2}{|c|}{$9.52 \%$} \\
\hline \multicolumn{5}{|c|}{ Panel B: Incorporating bank size categories } \\
\hline & \multicolumn{2}{|c|}{ SIC61 } & \multicolumn{2}{|c|}{ High REC/TA } \\
\hline Intercept & -13.240 & $(0.961)$ & -15.779 & $(0.935)$ \\
\hline$B 1050$ & 0.578 & $(0.044)$ & -0.016 & $(0.930)$ \\
\hline B50_100 & 0.155 & (0.729) & -0.161 & $(0.683)$ \\
\hline B100_500 & -0.361 & (0.532) & -7.140 & $(0.980)$ \\
\hline$B 500^{-}$ & 0.034 & (0.935) & -0.206 & $(0.498)$ \\
\hline BANK & -0.017 & (0.925) & -0.246 & $(0.008)$ \\
\hline BANK*B10_50 & -0.838 & $(0.006)$ & -0.127 & (0.555) \\
\hline$B A N K^{*} B 50^{-} 100$ & -1.053 & (0.110) & -0.669 & $(0.290)$ \\
\hline BANK*B100_500 & -0.598 & (0.361) & 6.299 & (0.982) \\
\hline BANK ${ }^{*} B 500$ & -7.657 & (0.977) & -6.912 & (0.972) \\
\hline Control variables & \multicolumn{2}{|c|}{ Yes } & \multicolumn{2}{|c|}{ Yes } \\
\hline Year fixed effects & \multicolumn{2}{|c|}{ Yes } & \multicolumn{2}{|c|}{ Yes } \\
\hline Observations & \multicolumn{2}{|c|}{5,938} & \multicolumn{2}{|c|}{7,717} \\
\hline McFadden's $\mathrm{R}^{2}$ & \multicolumn{2}{|c|}{$9.65 \%$} & \multicolumn{2}{|c|}{$10.37 \%$} \\
\hline \multicolumn{5}{|c|}{ 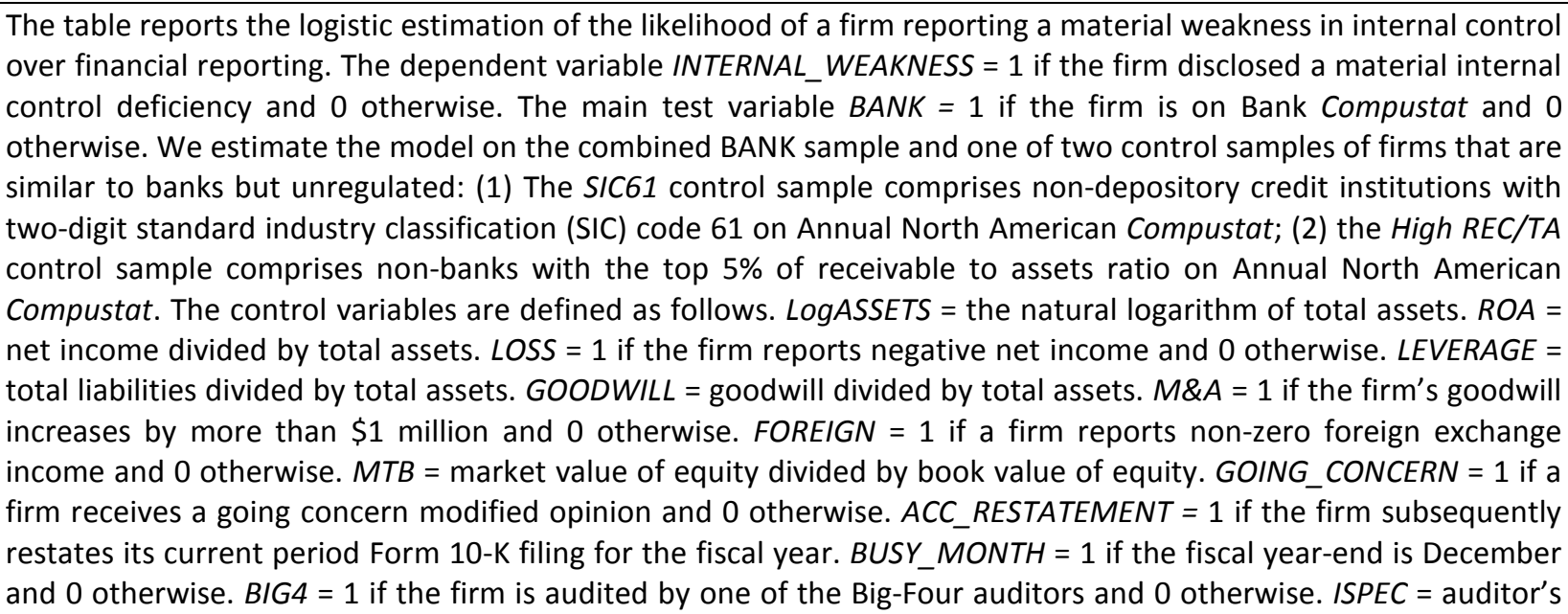 } \\
\hline
\end{tabular}


relative market share of audit fees in the client's Fama-French 48 industry classification. Panel A reports the base model estimation. Panel B reports the estimation of an expanded model which includes firm size indicators and their interactions with $B A N K$. The firm size indicators are denoted $B j_{-} k=1$ if total assets are between $\mathrm{j}$ and $\mathrm{k} \$$ billion, for $\mathrm{j}=10,50$, or 100 and for $\mathrm{k}=50,100$, or 500 and are denoted $B 500=1$ if total assets exceed $\$ 500$ billion. $p$ values are reported in parentheses. 
Table 3

Likelihood of financial statement restatements for banks versus control firms

\begin{tabular}{|c|c|c|c|c|}
\hline \multicolumn{5}{|c|}{ Panel A: Logistic estimation of restatements } \\
\hline \multirow[b]{2}{*}{ BANK } & \multicolumn{2}{|c|}{ SIC61 } & \multicolumn{2}{|c|}{ High REC/TA } \\
\hline & -0.527 & $(0.006)$ & -0.746 & $(0.000)$ \\
\hline LogASSETS & 0.014 & $(0.868)$ & 0.088 & (0.110) \\
\hline$R O A$ & 0.150 & (0.938) & -0.854 & (0.219) \\
\hline LOSS & 0.145 & $(0.424)$ & 0.191 & $(0.144$ \\
\hline LEVERAGE & -0.789 & (0.499) & 0.840 & (0.178) \\
\hline GOODWILL & -13.145 & $(0.152)$ & -5.957 & (0.013) \\
\hline$M \& A$ & 0.277 & $(0.105)$ & 0.257 & (0.041) \\
\hline FOREIGN & -0.664 & $(0.308)$ & -0.804 & (0.029) \\
\hline MTB & -0.060 & $(0.708)$ & 0.049 & (0.084) \\
\hline GOING_CONCERN & -5.523 & $(0.972)$ & -7.079 & (0.980) \\
\hline INTERNAL_WEAKNESS (Y_CONTROL) & -0.116 & $(0.753)$ & 0.004 & (0.988) \\
\hline BUSY_MONTH & -0.017 & $(0.929)$ & -0.223 & (0.055) \\
\hline$B I G 4^{-}$ & 0.574 & $(0.084)$ & 0.332 & (0.099) \\
\hline ISPEC & -2.359 & $(0.338)$ & -1.782 & (0.226) \\
\hline Intercept & 48.739 & $(0.983)$ & 10.812 & (0.969) \\
\hline Year fixed effects & $\mathrm{Y}$ & & & \\
\hline Observations & 8,4 & & & \\
\hline McFadden's $\mathrm{R}^{2}$ & 7.7 & & & \\
\hline \multicolumn{5}{|c|}{ Panel B: Incorporating bank size into the analyses } \\
\hline & \multicolumn{2}{|c|}{ SIC61 } & \multicolumn{2}{|c|}{ High REC/TA } \\
\hline Intercept & 26.817 & $(0.956)$ & 26.439 & (0.962) \\
\hline B10_50 & 0.247 & $(0.564)$ & -0.006 & (0.981) \\
\hline B50_100 & -0.039 & (0.951) & -0.359 & (0.516) \\
\hline B100_500 & 0.293 & $(0.600)$ & -0.224 & (0.607) \\
\hline$B 500$ & -6.600 & (0.975) & -0.566 & (0.230) \\
\hline BANK & -0.283 & $(0.281)$ & -0.667 & $(0.000)$ \\
\hline BANK*B10_50 & -1.386 & $(0.031)$ & -1.064 & $(0.052)$ \\
\hline BANK ${ }^{*} B 50 \_100$ & -6.590 & (0.978) & -6.580 & (0.985) \\
\hline BANK*B100_500 & -0.406 & (0.438) & 0.217 & (0.643) \\
\hline BANK*B500 & -0.585 & (0.999) & -6.695 & (0.985) \\
\hline Control variables & \multicolumn{2}{|c|}{ Yes } & \multicolumn{2}{|c|}{ Yes } \\
\hline Year fixed effects & \multicolumn{2}{|c|}{ Yes } & \multicolumn{2}{|c|}{ Yes } \\
\hline Observations & \multicolumn{2}{|c|}{8,436} & \multicolumn{2}{|c|}{10,882} \\
\hline McFadden's $R^{2}$ & \multicolumn{2}{|c|}{$10.40 \%$} & \multicolumn{2}{|c|}{$10.37 \%$} \\
\hline
\end{tabular}

The table reports the logistic estimation of the likelihood of a firm reporting a financial statement restatement. The dependent variable ACC_RESTATEMENT $=1$ if the firm subsequently restated its 10-K filing for the fiscal year and zero otherwise. The main test variable $B A N K=1$ if the firm is on Bank Compustat and 0 otherwise. We estimate the model on the combined BANK sample and one of two control samples of firms that are similar to banks but unregulated: (1) The SIC61 control sample comprises non-depository credit institutions with two-digit standard industry classification (SIC) code 61 on Annual North American Compustat; (2) the High REC/TA control sample comprises non-banks with the top $5 \%$ of receivable to assets ratio on Annual North American Compustat. The control variables are defined as follows. LOgASSETS = the natural logarithm of total assets. ROA = net income divided by total assets. LOSS $=1$ if the firm reports negative net income and 0 otherwise. LEVERAGE $=$ total liabilities divided by total assets. GOODWILL = goodwill divided by total assets. $M \& A=1$ if the firm's goodwill increases by more than $\$ 1$ million and 0 otherwise. FOREIGN = 1 if a firm reports non-zero foreign exchange income and 0 otherwise. MTB = market value of equity divided by book value of equity. GOING_CONCERN = 1 if a firm receives a going concern modified opinion and 0 otherwise. INTERNAL_WEAKNESS $=1$ if the firm disclosed internal control deficiencies and 0 otherwise. BUSY_MONTH $=1$ if the fiscal year-end is December and 0 otherwise. $B I G 4=1$ if the firm is audited by one of the Big-Four auditors and 0 otherwise. ISPEC = auditor's relative market 
share of audit fees in the client's Fama-French 48 industry classification. Panel A reports the base model estimation. Panel B reports the estimation of an expanded model which includes firm size indicators and their interactions with $B A N K$. The firm size indicators are denoted $B j \_k=1$ if total assets are between $\mathrm{j}$ and $\mathrm{k} \$$ billion, for $\mathrm{j}=10,50$, or 100 and for $\mathrm{k}=50,100$, or 500 and are denoted $B 500=1$ if total assets exceed $\$ 500$ billion. $p$-values are reported in parentheses. 
Table 4

Audit fees for banks versus control firms

\begin{tabular}{|c|c|c|c|c|}
\hline \multicolumn{5}{|c|}{ Panel A: OLS estimation of audit fees } \\
\hline & \multicolumn{4}{|c|}{ CONTROL } \\
\hline & \multicolumn{2}{|c|}{ SIC61 } & \multicolumn{2}{|c|}{ High REC/TA } \\
\hline BANK & -0.711 & $(0.000)$ & -0.950 & $(0.000)$ \\
\hline LOgASSETS & 0.597 & $(0.000)$ & 0.549 & $(0.000)$ \\
\hline$R O A$ & -0.735 & $(0.003)$ & -0.740 & $(0.000)$ \\
\hline LOSS & 0.179 & $(0.000)$ & 0.200 & $(0.000)$ \\
\hline SPECIAL ITEMS & 0.478 & $(0.003)$ & 0.054 & $(0.733)$ \\
\hline DISCONTINUED & 0.297 & $(0.000)$ & 0.230 & $(0.000)$ \\
\hline LEVERAGE & -1.507 & $(0.000)$ & -0.626 & $(0.000)$ \\
\hline INVENTORY & 0.278 & (0.196) & 0.724 & $(0.000)$ \\
\hline INTANGIBLES & 2.585 & $(0.002)$ & 2.452 & $(0.000)$ \\
\hline GOODWILL & -2.494 & $(0.065)$ & -0.637 & $(0.278)$ \\
\hline$M \& A$ & 0.082 & $(0.000)$ & 0.095 & $(0.000)$ \\
\hline NEG_EQUITY & 0.224 & $(0.103)$ & 0.468 & $(0.000)$ \\
\hline FIRM_AGE & 0.004 & $(0.042)$ & 0.008 & $(0.000)$ \\
\hline ACCEL FILER & 0.001 & $(0.975)$ & 0.033 & $(0.259)$ \\
\hline INTERNAL_WEAKNESS & 0.257 & $(0.000)$ & 0.276 & $(0.000)$ \\
\hline МTB & -0.009 & $(0.537)$ & 0.020 & $(0.006)$ \\
\hline RETURN & -0.033 & $(0.070)$ & 0.001 & $(0.960)$ \\
\hline$S T D_{-} R E T U R N$ & 0.803 & $(0.000)$ & 0.736 & $(0.000)$ \\
\hline GOING_CONCERN & 0.067 & $(0.478)$ & 0.069 & $(0.377)$ \\
\hline BUSY $\bar{M} O N T H$ & 0.086 & $(0.045)$ & 0.017 & $(0.627)$ \\
\hline$B I G 4$ & 0.316 & $(0.000)$ & 0.325 & $(0.000)$ \\
\hline ISPEC & 0.084 & $(0.725)$ & 0.219 & $(0.183)$ \\
\hline Year fixed effects & Ye & & Ye & es \\
\hline Observations & 8,4 & & $10, \varepsilon$ & 882 \\
\hline Adjusted $\mathrm{R}^{2}$ & & $30 \%$ & & $20 \%$ \\
\hline \multicolumn{5}{|c|}{ Panel B: Incorporating firm size into the analyses } \\
\hline & \multicolumn{2}{|c|}{ SIC61 } & \multicolumn{2}{|c|}{ High REC/TA } \\
\hline$B 1050$ & -0.217 & $(0.261)$ & 0.023 & $(0.889)$ \\
\hline$B 50-100$ & 0.266 & $(0.091)$ & 0.301 & $(0.010)$ \\
\hline B100_500 & 0.195 & $(0.528)$ & 0.197 & $(0.321)$ \\
\hline$B 500^{-}$ & 0.472 & $(0.005)$ & 0.519 & $(0.000)$ \\
\hline BANK & -0.767 & $(0.000)$ & -0.970 & $(0.000)$ \\
\hline BANK*B10_50 & 0.211 & $(0.283)$ & 0.022 & (0.895) \\
\hline BANK*B50 100 & -0.183 & $(0.335)$ & -0.128 & $(0.434)$ \\
\hline BANK*B100_500 & 0.205 & $(0.512)$ & 0.320 & (0.114) \\
\hline BANK*B500 & 0.705 & $(0.000)$ & 0.849 & $(0.000)$ \\
\hline Control variables & \multicolumn{2}{|c|}{ Yes } & \multicolumn{2}{|c|}{ Yes } \\
\hline Year fixed effects & \multicolumn{2}{|c|}{ Yes } & \multicolumn{2}{|c|}{ Yes } \\
\hline Observations & \multicolumn{2}{|c|}{8,436} & \multicolumn{2}{|c|}{10,882} \\
\hline Adjusted $\mathrm{R}^{2}$ & \multicolumn{2}{|c|}{$90.58 \%$} & \multicolumn{2}{|c|}{$88.96 \%$} \\
\hline \multicolumn{5}{|c|}{$\begin{array}{l}\text { The table reports the OLS estimation of a model with dependent variable LogFEE = the natural logarithm of the } \\
\text { sum of audit fees and audit-related fees. The main test variable BANK = } 1 \text { if the firm is on Bank Compustat and } 0 \\
\text { otherwise. We estimate the model on the combined BANK sample and one of two control samples of firms that are } \\
\text { similar to banks but unregulated: (1) The SIC61 control sample comprises non-depository credit institutions with } \\
\text { two-digit standard industry classification (SIC) code } 61 \text { on Annual North American Compustat; ( } 2 \text { ) the High REC/TA } \\
\text { control sample comprises non-banks with the top } 5 \% \text { of receivable to assets ratio on Annual North American } \\
\text { Compustat. The control variables are defined as follows. LogASSETS = the natural logarithm of total assets. ROA = } \\
\text { net income divided by total assets. LOSS = } 1 \text { if the firm reports negative net income and } 0 \text { otherwise. } \\
\text { SPECIAL_ITEMS = special items divided by total assets. DISCONTINUED = } 1 \text { if a firm's discontinued operations }\end{array}$} \\
\hline
\end{tabular}


exceeds $\$ 1$ million and 0 otherwise. LEVERAGE = total liabilities divided by total assets. INVENTORY = inventory divided by total assets. INTANGIBLES = intangible assets divided by total assets. GOODWILL = goodwill divided by total assets. $M \& A=1$ if the firm's goodwill increases by more than $\$ 1$ million and 0 otherwise. NEG_EQUITY $=1$ if common equity is negative and 0 otherwise. FIRM_AGE = the number of years the firm is listed in Compustat. ACCEL_FILER $=1$ if the firm is an accelerated filer and 0 otherwise. INTERNAL_WEAKNESS $=1$ if the firm disclosed a material internal control deficiency and 0 otherwise. $M T B=$ market value of equity divided by book value of equity. RETURN = fiscal year stock return. STD_RETURN = standard deviation of monthly stock returns. GOING_CONCERN = 1 if a firm receives a going concern modified opinion and 0 otherwise. BUSY_MONTH = 1 if the fiscal year-end is December and 0 otherwise. $B I G 4=1$ if the firm is audited by one of the Big-Four auditors and 0 otherwise. ISPEC = auditor's relative market share of audit fees in the client's Fama-French 48 industry classification. Panel A reports the base model estimation. Panel B reports the estimation of an expanded model which includes firm size indicators and their interactions with $B A N K$. The firm size indicators are denoted $B j_{-} k=1$ if total assets are between $\mathrm{j}$ and $\mathrm{k} \$$ billion, for $\mathrm{j}=10,50$, or 100 and for $\mathrm{k}=50,100$, or 500 and are denoted $B 500=1$ if total assets exceed $\$ 500$ billion. Standard errors are clustered at the firm level (two-tailed $p$-values are in parentheses). 
Table 5

Audit report lag for banks versus control firms

\begin{tabular}{|c|c|c|c|c|}
\hline \multicolumn{5}{|c|}{ Panel A: OLS estimation of audit report lag } \\
\hline & \multicolumn{2}{|c|}{ SIC61 } & \multicolumn{2}{|c|}{ High REC/TA } \\
\hline BANK & -0.089 & $(0.033)$ & -0.095 & $(0.000)$ \\
\hline LogASSETS & -0.015 & $(0.044)$ & -0.021 & $(0.000)$ \\
\hline$R O A$ & -0.285 & (0.012) & 0.053 & $(0.283)$ \\
\hline LOSS & 0.111 & (0.000) & 0.142 & $(0.000)$ \\
\hline DISCONTINUED & 0.039 & (0.290) & 0.039 & (0.111) \\
\hline EXTRA_ITEMS & 0.100 & (0.056) & 0.141 & $(0.000)$ \\
\hline$A B S \_\overline{A C C} C R \cup A L S$ & -0.026 & (0.229) & 0.064 & $(0.060)$ \\
\hline LEVERAGE & 0.050 & $(0.652)$ & 0.071 & $(0.152)$ \\
\hline INVENTORY & 0.426 & (0.001) & 0.248 & (0.007) \\
\hline FOREIGN & 0.206 & $(0.002)$ & 0.076 & $(0.026)$ \\
\hline FIRM_AGE & -0.006 & $(0.000)$ & -0.004 & $(0.000)$ \\
\hline INTERNAL_WEAKNESS & 0.193 & (0.000) & 0.166 & $(0.000)$ \\
\hline AUDITOR_TURNOVER & 0.042 & (0.007) & 0.048 & $(0.000)$ \\
\hline GOING_CONCERN & 0.239 & (0.001) & 0.170 & $(0.000)$ \\
\hline BUSY_MONONH & -0.051 & (0.043) & -0.043 & $(0.025)$ \\
\hline BIG4 & 0.104 & $(0.000)$ & 0.075 & $(0.000)$ \\
\hline Year fixed effects & $Y e$ & & Ye & \\
\hline Observations & 8,1 & & 10,5 & \\
\hline Adjusted $\mathrm{R}^{2}$ & 49. & $7 \%$ & 44.3 & $37 \%$ \\
\hline \multicolumn{5}{|c|}{ Panel B: Incorporating firm size into the analyses } \\
\hline & \multicolumn{2}{|c|}{ SIC61 } & \multicolumn{2}{|c|}{ High REC/TA } \\
\hline B10_50 & -0.244 & 0.000 & -0.119 & (0.001) \\
\hline$B 50-100$ & -0.205 & 0.049 & -0.082 & $(0.161)$ \\
\hline B100_500 & -0.203 & 0.006 & 0.063 & $(0.440)$ \\
\hline$B 500$ & 0.071 & 0.658 & 0.148 & $(0.082)$ \\
\hline BANK & -0.157 & 0.001 & -0.132 & $(0.000)$ \\
\hline BANK*B10_50 & 0.229 & 0.001 & 0.169 & $(0.000)$ \\
\hline BANK*B50_100 & 0.244 & 0.049 & 0.219 & $(0.013)$ \\
\hline BANK*B100_500 & 0.265 & 0.005 & 0.133 & (0.199) \\
\hline BANK*B500 & 0.079 & 0.647 & 0.189 & (0.136) \\
\hline Control variables & \multicolumn{2}{|c|}{ Yes } & \multicolumn{2}{|c|}{ Yes } \\
\hline Year fixed effects & \multicolumn{2}{|c|}{ Yes } & \multicolumn{2}{|c|}{ Yes } \\
\hline Observations & \multicolumn{2}{|c|}{8,150} & \multicolumn{2}{|c|}{10,529} \\
\hline Adjusted $\mathrm{R}^{2}$ & \multicolumn{2}{|c|}{$50.29 \%$} & \multicolumn{2}{|c|}{$45.02 \%$} \\
\hline \multicolumn{5}{|c|}{ 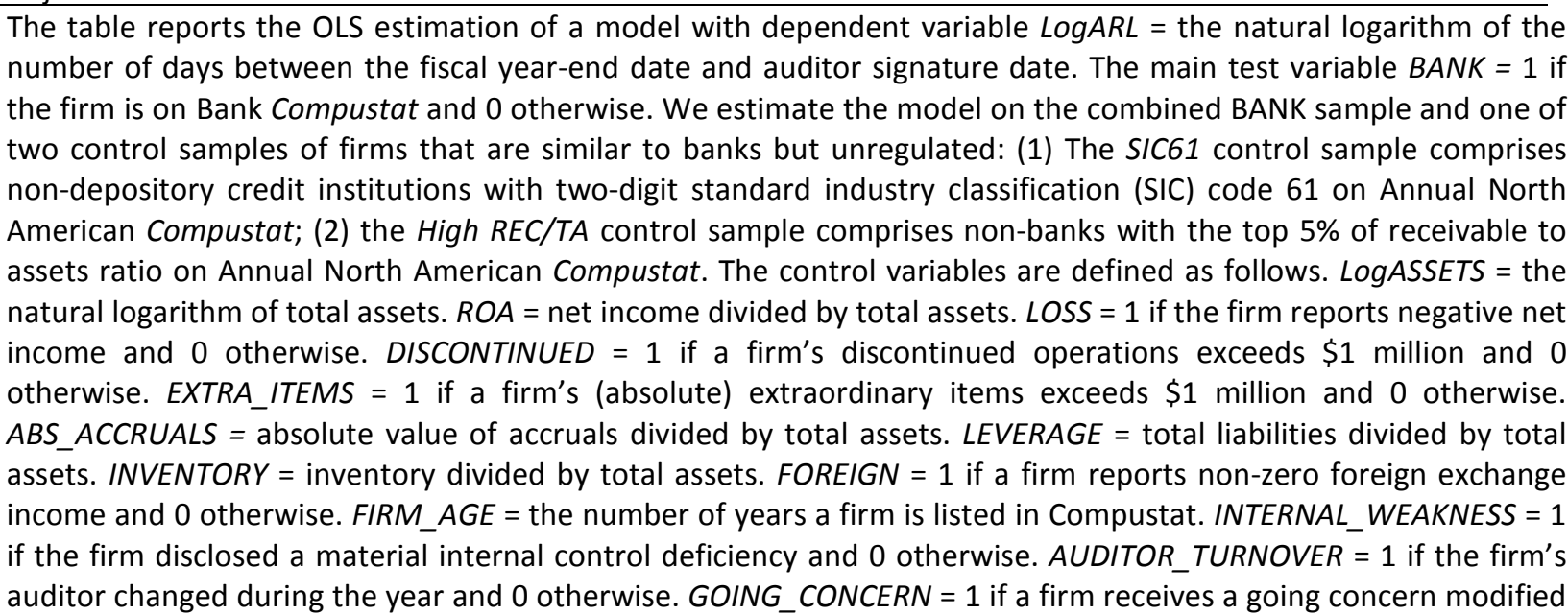 } \\
\hline
\end{tabular}


opinion and 0 otherwise. BUSY_MONTH = 1 if the fiscal year-end is December and 0 otherwise. BIG4 $=1$ if the firm is audited by one of the Big-Four auditors and 0 otherwise. Panel A reports the base model estimation. Panel $B$ reports the estimation of an expanded model which includes firm size indicators and their interactions with BANK. The firm size indicators are denoted $B j_{-} k=1$ if total assets are between $\mathrm{j}$ and $\mathrm{k} \$$ billion, for $\mathrm{j}=10,50$, or 100 and for $k=50,100$, or 500 and are denoted $B 500=1$ if total assets exceed $\$ 500$ billion. Standard errors are clustered at the firm level (two-tailed $p$-values are in parentheses). 
Table 6

Identification tests for audit fee model using proxies for times-series variation

in the intensity of banking regulation

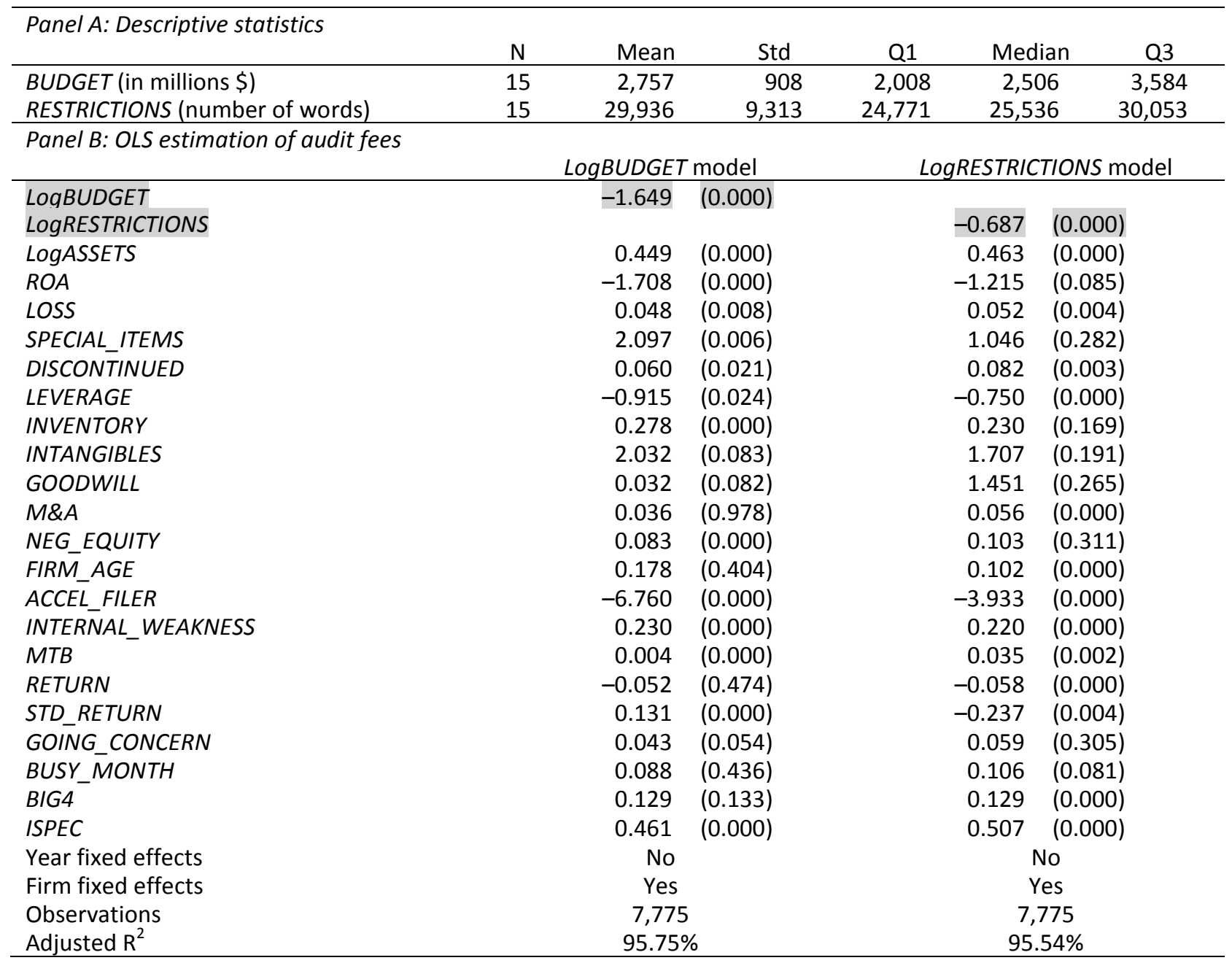

Panel A reports descriptive statistics for two measures of bank regulation intensity, BUDGET and RESTRICTIONS. $B U D G E T$ is the annual budget in \$ millions of the "finance and banking" subcategory (which includes the Comptroller of the Currency, Federal Deposit Insurance Corporation, and Securities and Exchange Commission) from Regulatory Reports available at https://wc.wustl.edu/regulatory reports. RESTRICTIONS is based on RegData, an industry- and year-specific regulation index constructed by Al-Ubaydli and McLaughlin (2017) from textual analysis of the number of constraints (the strings "shall," "must," "may not," "prohibited," and "required") in the Code of Federal Regulations (CFR) Title 12 for the banking industry each year. Panel B reports the OLS estimation, for the BANK sample only, of an expansion of the audit fee model with dependent variable LogFEE = the natural logarithm of the sum of audit fees and audit-related fees reported in Table 4. The expanded model includes the natural logarithm of BUDGET or RESTRICTIONS. The control variables are defined as follows. LOgASSETS $=$ the natural logarithm of total assets. $R O A=$ net income divided by total assets. $L O S S=1$ if the firm reports negative net income and 0 otherwise. SPECIAL_ITEMS = special items divided by total assets. DISCONTINUED = 1 if a firm's discontinued operations exceeds $\$ 1$ million and 0 otherwise. $\angle E V E R A G E=$ total liabilities divided by total assets. INVENTORY = inventory divided by total assets. INTANGIBLES = intangible assets divided by total assets. GOODWILL = goodwill divided by total assets. $M \& A=1$ if the firm's goodwill increases by more than $\$ 1$ million and 0 otherwise. NEG_EQUITY = 1 if common equity is negative and 0 otherwise. FIRM_AGE = the number of years a firm is listed in Compustat. ACCEL_FILER $=1$ if the firm is an accelerated filer and 0 otherwise. INTERNAL_WEAKNESS $=1$ 
if the firm disclosed a material internal control deficiency and 0 otherwise. MTB = market value of equity divided by book value of equity. RETURN = fiscal year stock return. STD_RETURN = standard deviation of monthly stock returns. GOING_CONCERN $=1$ if a firm receives a going concern modified opinion and 0 otherwise. BUSY_MONTH $=1$ if the fiscal year-end is December and 0 otherwise. BIG4 = 1 if the firm is audited by one of the Big-Four auditors and 0 otherwise. ISPEC = auditor's relative market share of audit fees in the client's Fama-French 48 industry classification. Standard errors are White's corrected standard errors (two-tailed $p$-values are in parentheses). 


\section{Table 7}

Identification tests for audit fee model using proxy for cross sectional variation in the intensity of banking regulation

\begin{tabular}{|c|c|c|c|c|}
\hline & \multicolumn{2}{|c|}{ STATE BANKS } & \multicolumn{2}{|c|}{ ALL BANKS } \\
\hline STATE_REG & 0.656 & $(0.017)$ & -0.719 & $(0.151)$ \\
\hline STATE_BANK & & & -0.084 & (0.170) \\
\hline STATE_REG $\times$ STATE_BANK & & & 1.379 & (0.017) \\
\hline LogASSETS & 0.536 & $(0.000)$ & 0.566 & $(0.000)$ \\
\hline$R O A$ & -3.974 & $(0.008)$ & -4.262 & $(0.003)$ \\
\hline LOSS & 0.089 & $(0.010)$ & 0.116 & $(0.001)$ \\
\hline SPECIAL_ITEMS & 3.163 & $(0.055)$ & 3.754 & $(0.015)$ \\
\hline DISCONTINUED & 0.303 & $(0.001)$ & 0.281 & $(0.000)$ \\
\hline LEVERAGE & -1.975 & $(0.000)$ & -1.973 & $(0.000)$ \\
\hline INVENTORY & 0.786 & $(0.000)$ & 0.929 & $(0.000)$ \\
\hline INTANGIBLES & 7.248 & $(0.000)$ & 7.018 & $(0.000)$ \\
\hline GOODWILL & -5.498 & $(0.000)$ & -5.478 & $(0.000)$ \\
\hline$M \& A$ & 0.091 & $(0.000)$ & 0.066 & $(0.000)$ \\
\hline NEG_EQUITY & 0.178 & $(0.152)$ & 0.025 & $(0.893)$ \\
\hline FIRM_AGE & 0.007 & $(0.002)$ & 0.008 & $(0.000)$ \\
\hline ACCEL FILER & 0.072 & $(0.020)$ & 0.021 & $(0.464)$ \\
\hline INTERNALL_WEAKNESS & 0.248 & $(0.000)$ & 0.246 & $(0.000)$ \\
\hline МTB & 0.005 & $(0.740)$ & -0.004 & $(0.764)$ \\
\hline RETURN & -0.048 & (0.009) & -0.023 & (0.197) \\
\hline STD_RETURN & 0.748 & $(0.000)$ & 0.703 & $(0.000)$ \\
\hline GOING_CONCERN & -0.069 & $(0.416)$ & 0.035 & $(0.710)$ \\
\hline BUSY MNONTH & 0.068 & $(0.057)$ & 0.066 & $(0.070)$ \\
\hline$B I G 4$ & 0.366 & $(0.000)$ & 0.333 & $(0.000)$ \\
\hline ISPEC & 0.015 & (0.952) & -0.005 & (0.982) \\
\hline Intercept & 9.331 & $(0.000)$ & 9.267 & $(0.000)$ \\
\hline Year fixed effects & & es & $Y \epsilon$ & \\
\hline Observations & & 597 & 7,2 & \\
\hline Adjusted $\mathrm{R}^{2}$ & & $29 \%$ & 88.4 & \\
\hline
\end{tabular}

The table reports the OLS estimation, for the BANK sample only, of two expansions of the audit fee model with dependent variable LogFEE = the natural logarithm of the sum of audit fees and audit-related fees in $\$$ millions reported in Table 4. The both expanded models include Agarwal, Lucca, Seru and Trebbi's (2014) measure of regulatory leniency (inverse intensity) across state-chartered banks (STATE_REG) and The measure is based on the "alternating examination program" in which state-chartered banks are examined by (more stringent) federal supervisors (the FDIC or Federal Reserve) and state supervisors on an alternating basis. Using a proprietary database, Agarwal et al. (2014) estimate the differential examination stringency of federal supervisors versus 44 state bank supervisors. The expanded reported in right column as includes an indicator for whether bank is a statechartered bank (STATE_BANK) based on information obtained from the FDIC website (https://www5.fdic.gov/idasp/advSearchLanding.asp), as well as the interaction of STATE_REG with STATE_BANK. The control variables are defined as follows. LOgASSETS = the natural logarithm of total assets. ROA = net income divided by total assets. $L O S S=1$ if the firm reports negative net income and 0 otherwise. SPECIAL_ITEMS = special items divided by total assets. DISCONTINUED $=1$ if a firm's discontinued operations exceeds $\$ 1$ million and 0 otherwise. LEVERAGE = the total liabilities divided by total assets. INVENTORY = inventory divided by total assets. INTANGIBLES = intangible assets divided by total assets. GOODWILL = goodwill divided by total assets. $M \& A=1$ if the firm's goodwill increases by more than $\$ 1$ million and 0 otherwise. NEG_EQUITY $=1$ if common equity is negative and 0 otherwise. FIRM_AGE = the number of years a firm is listed in Compustat. ACCEL_FILER $=1$ if the firm is an accelerated filer and 0 otherwise. INTERNAL_WEAKNESS $=1$ if the firm disclosed a material internal control deficiency and 0 otherwise. $M T B=$ market value of equity divided by book value of equity. RETURN = fiscal year stock return. STD_RETURN = standard deviation of monthly stock returns. GOING_CONCERN = 1 if a firm receives a going concern modified opinion and 0 otherwise. BUSY_MONTH $=1$ if the fiscal year-end is December 
and 0 otherwise. BIG4 = 1 if the firm is audited by one of the Big-Four auditors and 0 otherwise. ISPEC = auditor's relative market share of audit fees in the client's Fama-French 48 industry classification. Standard errors are clustered at the firm level (two-tailed $p$-values are in parentheses). 
Table 8

Likelihood of small earnings increases for banks versus control firms

\begin{tabular}{|c|c|c|c|c|}
\hline & & & & \\
\hline & & & High & $E C / T A$ \\
\hline BANK & 0.730 & $(0.000)$ & 0.683 & $(0.000)$ \\
\hline LogASSETS & -0.052 & $(0.030)$ & 0.001 & (0.951) \\
\hline LEVERAGE & -1.321 & $(0.007)$ & -0.879 & (0.002) \\
\hline MTB & 0.037 & $(0.232)$ & -0.039 & $(0.066)$ \\
\hline ACCEL_FILER & 0.101 & $(0.008)$ & 0.107 & $(0.003)$ \\
\hline BIG4 & -0.028 & $(0.445)$ & -0.043 & $(0.211)$ \\
\hline Intercept & -2.065 & $(0.000)$ & -2.688 & $(0.000)$ \\
\hline Year fixed effects & & & & \\
\hline Observations & & & & \\
\hline McFadden's $\mathrm{R}^{2}$ & & & & \\
\hline
\end{tabular}

The table reports the logistic estimation of the likelihood that a firm reports a small earnings increase. SMALL_POS

$=1$ if $0.00<\triangle R O E \leq 0.01$, where ROE = net income divided by the book value of common equity, and 0 otherwise.

The main test variable $B A N K=1$ if the firm is a bank and 0 otherwise. We estimate the model on the combined BANK sample and one of two control samples of firms that are similar to banks but unregulated: (1) The SIC61 control sample comprises non-depository credit institutions with two-digit standard industry classification (SIC) code 61 on Annual North American Compustat; (2) the High REC/TA control sample comprises non-banks with the top $5 \%$ of receivable to assets ratio on Annual North American Compustat. The control variables are defined as follows. LOgASSETS = the natural logarithm of total assets. $L E V E R A G E=$ total liabilities divided by total assets. MTB $=$ market value of equity divided by book value of equity. ACCEL_FILER $=1$ if the firm is an accelerated filer and 0 otherwise. $B I G 4=1$ if the firm is audited by one of the Big-Four auditors and 0 otherwise. $p$-values are reported in parentheses. 
Table 9

Length of string of consecutive earnings increases for banks versus control firms

\begin{tabular}{lrrrr}
\hline & \multicolumn{3}{c}{ CONTROL } \\
\cline { 2 - 6 } & \multicolumn{2}{c}{ SIC61 } & \multicolumn{2}{c}{ High REC/TA } \\
\hline BANK & 0.370 & $(0.011)$ & 0.666 & $(0.000)$ \\
LOgASSETS & -0.129 & $(0.000)$ & -0.173 & $(0.000)$ \\
LEVERAGE & -0.507 & $(0.340)$ & 0.548 & $(0.000)$ \\
MTB & -0.277 & $(0.000)$ & -0.058 & $(0.000)$ \\
GOODWILL & 1.020 & $(0.459)$ & -0.727 & $(0.069)$ \\
ACCEL_FILER & 0.431 & $(0.000)$ & 0.243 & $(0.000)$ \\
INTERNAL_WEAKNESS & 0.129 & $(0.574)$ & -0.063 & $(0.633)$ \\
BIG4 & -0.105 & $(0.196)$ & -0.111 & $(0.058)$ \\
Year fixed effects & \multicolumn{2}{c}{ Yes } & \multicolumn{2}{c}{ Yes } \\
Number of observations & \multicolumn{2}{c}{1,065} & 1,775 \\
McFadden's R R & \multicolumn{2}{c}{$3.92 \%$} & $3.67 \%$ \\
\hline
\end{tabular}

The table reports proportional hazard model estimation of a model with dependent variable STRING = the duration of the longest string of consecutive annual earnings increases. The main test variable $B A N K=1$ if the firm is a bank, and 0 otherwise. We estimate the model on the combined BANK sample and one of two control samples of firms that are similar to banks but unregulated: (1) The SIC61 control sample comprises non-depository credit institutions with two-digit standard industry classification (SIC) code 61 on Annual North American Compustat; (2) the High REC/TA control sample comprises non-banks with the top $5 \%$ of receivable to assets ratio on Annual North American Compustat. The control variables are defined as follows. LogASSETS = the natural logarithm of total assets. $L E V E R A G E=$ total liabilities divided by total assets. $M T B=$ market value of equity divided by book value of equity. ACCEL_FILER $=1$ if the firm is an accelerated filer and 0 otherwise. BIG4 $=1$ if the firm is audited by one of the Big-Four auditors and 0 otherwise. $p$-values are reported in parentheses. 


\section{Figure 1}

Plot of time-series measures of the intensity of banking regulation from 2000-2014

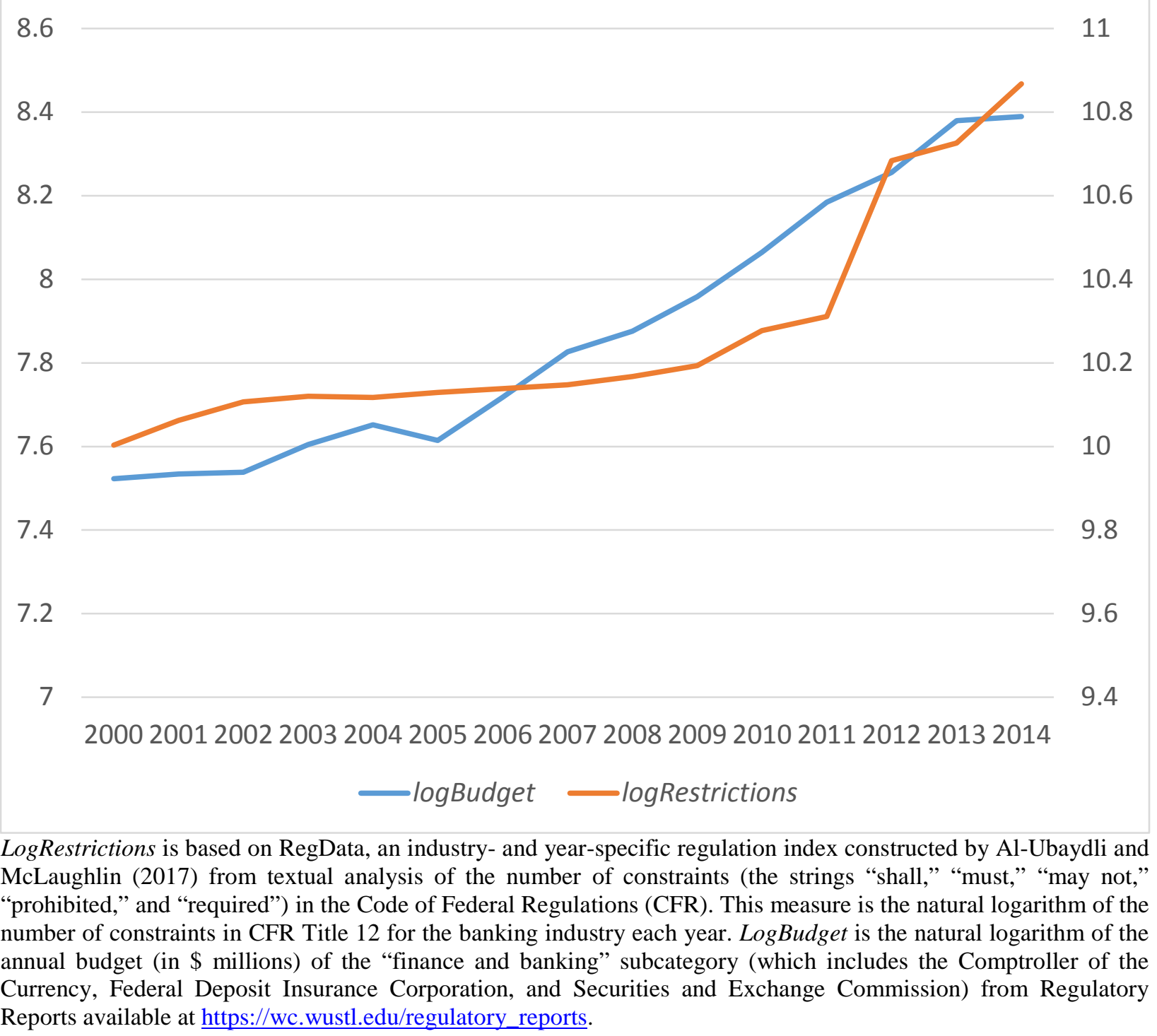

